\title{
Feasibility of Zero Energy Multi-Family Low Income Housing Tax Credit (LIHTC) Developments
}

Armin J. Yeganeh ${ }^{a *}$, Philip R. Agee ${ }^{\mathrm{a}}$, Xinghua Gao ${ }^{\mathrm{a}}$, Andrew P. McCoy

a) Myers-Lawson School of Construction, Virginia Tech, USA

* Corresponding author: Armin J. Yeganeh, 1345 Perry St, Blacksburg, VA 24060, USA

Email: yeganeh@vt.edu

Word count: $\sim 8000$ words (Excluding the abstract, highlights, figures, tables, captions, references $)+(10)$ tables $+(10)$ figures $+(4)$ appendix tables $+(1)$ appendix figure

Running title: Zero-Energy Low-Income Housing 0(0)

Acknowledgments: None.

Competing financial interest: The authors declare they have no competing financial interest.

Funding: This research did not receive any specific grants from funding agencies in the public, commercial, or not-for-profit sectors. 


\section{Contents}

Abstract

1. Introduction

2. Literature Review

2.1. Energy-efficient low-income housing

2.2. Zero-energy buildings

2.3. Cost-benefit analysis and simulation-based risk analysis

3. Methodology

3.1. Analysis framework

3.2. Data collection

3.3. Statistical analysis of loads

3.4. Study case and PV system simulation

3.5. Feasibility analysis

4. Results

4.1. Load profiles

4.2. PV system simulation

4.3. Discounted cash flow analysis

5. Discussion

5.1. Key results and comparison with previous research

5.2. Technology adoption barriers and opportunities

5.3. Recommendations

6. Conclusion 


\begin{abstract}
The residential sector in the United States is in need of comprehensive policy-making reforms that concurrently address housing affordability and environmental sustainability. This study investigates the feasibility of state-wide zero-energy affordable housing by analyzing historical data on climate, energy use, and solar system costs in the Commonwealth of Virginia. The hypothesis examined is that the net present cost of implementation of rooftop residential solar systems to achieve zero-energy Low-Income Housing Tax Credit (LIHTC) buildings is lower than the discounted present cost of energy of otherwise identical conventional buildings that run without renewable energy generation systems. The authors propose a generalizable framework for analyzing the feasibility of achieving region- or state-wide zero-energy LIHTC developments. To validate the framework, the authors employ a longitudinal sample of monthly energy use data from 2013-2016 obtained from 310 residential units of 15 LIHTC developments across the state. Based on statistical regression analysis, energy simulation, and simulation-based risk analysis, the authors find that the net present value of zero-energy LIHTC investments can be positive with a low risk. The investment value varies often depending on the zero-energy building definition, weather characteristics, retail price of electricity, and incentive rate. This study can help housing policymakers and industry professionals analyze and benchmark the feasibility of innovative zeroenergy housing policies and projects.
\end{abstract}

Keywords: Affordable housing; Cost-benefit analysis; Monte Carlo simulation; Solar energy; 


\section{Highlights}

- Presents a framework for analyzing the feasibility of zero-energy affordable housing.

- Shows energy-efficiency measures significantly reduce energy use and emissions.

- Finds zero-energy affordable housing is feasible from energy and financial standpoints.

- Suggests states have a critical role in enabling zero-energy low-income housing.

- Describes additional support the industry needs to bridge the gap to zero-energy. 


\section{Introduction}

While renewable energy is rapidly growing in worldwide adoption, approximately 89 percent of the energy consumed in the US in 2019 still came from non-renewable sources like coal, gas, and nuclear power [1]. Of that energy produced, the residential sector accounted for approximately 21 percent of consumption. Simultaneously, almost half of all renter households are cost-burdened, often due to poverty and rapidly rising housing prices in large metro areas [2]. The residential sector in the US is clearly in need of comprehensive policy-making reforms that concurrently address affordability and environmental sustainability, reducing uncertainties around the national economy, energy security, declining natural resources, and climate change.

In 1986, the US Congress enacted the Low-Income Housing Tax Credit (LIHTC) program, which provides state LIHTC-allocating agencies with approximately $\$ 8$ billion per year to issue tax credits for the acquisition, rehabilitation, or new construction of rental housing for low-income households [3]. With more than 2.4 million active units [4], LIHTC is the principal federal housing production program, which incentivizes the production of a significant portion of below-marketrate multifamily rental units for extremely low-income to low-income households based on an indirect federal subsidy. Residents that qualify to live in a LIHTC unit benefit based on income and quality depending on their certified annual income and the maximum rent set by the project [5]. McClure (2019) describes the basics of the LIHTC program [6].

Energy-efficiency is increasingly considered important in LIHTC Qualified Allocation Plans (QAPs), which outline the criteria based on which state housing agencies allocate financial incentives in the form of tax credits to multi-family residential developers [7]. The basic federal criteria included in QAPs do not mandate specific energy-efficiency standards, but additional 
criteria that support state housing policy goals often include energy-efficiency incentives. Previous studies show QAPs have significant impacts on the location and quality of LIHTC developments [8]. As a result, QAPs could either promote or inhibit the application of innovative designs and technologies in low-income developments. Existing literature on the LIHTC program suggests that, among other co-benefits, energy-efficient LIHTC properties have generated considerable financial savings for the occupants [9]. Despite its significance as an opportunity to drive innovative solutions to address environmental sustainability and economic development in low-income housing in the U.S., zero-energy buildings have received little attention in low-income housing literature, policy, and practice. If proved to be more cost-effective, zero-energy developments benefit residents and society as a whole by increasing affordability, environmental sustainability, and efficient distribution of federal financial incentives.

This article explores the existing gap to zero energy in the context of the LIHTC program: how much should state housing agencies raise energy efficiency and renewable energy requirements to bridge the gap to zero-energy LIHTC apartments?; how much does a zero-energy LIHTC building cost to developers at the present time?; is a zero-energy LIHTC building more cost-effective than a conventional building over its lifecycle?; and what types of additional support does the construction industry need to bridge the gap to zero-energy? The main hypothesis examined is that the net present cost of the implementation of rooftop residential solar systems to achieve zeroenergy LIHTC buildings is lower than the discounted present cost of energy of otherwise identical conventional buildings that run without renewable energy generation systems. The authors propose a generalizable framework for analyzing the feasibility of achieving regional or state-wide zero energy in LIHTC developments. The framework is then validated using empirical data in a proofof-concept case study focused on the rooftop grid-connected photovoltaic (PV) system as the only 
source of harvesting renewable energy to offset 100 percent of a conventional multi-family residential building's annual energy demand in the Commonwealth of Virginia. This research addresses the knowledge gap in the literature and contributes to the body of knowledge through the examination of generalizable statistical energy load prediction methods and simulation-based risk analysis, which have essential applications in planning and policy analysis but are less explored in existing feasibility studies [10].

The following section sets forth a concise review of the literature on the need for energy-efficient low-income housing, the zero-energy building concept, and previous research on costs and benefits of zero-energy residential developments. Following the description of the analysis framework, the authors describe the study case, including the context, specifications, and related assumptions. Following steps are taken to test the research hypothesis and answer research questions: (1) Collecting data of LIHTC energy use, energy price, and state climatic divisions; (2) Predicting total energy load of the study case in the state climatic divisions; (3) Designing rooftop solar energy systems using simulation; (4) Estimating life-cycle cost analysis; (5) Deterministic and simulationbased feasibility analysis. Findings suggest that the net present value of zero-energy LIHTC apartments can be positive at a low risk. The investment value varies often depending on the zeroenergy building definition, project location, the retail price of electricity, and the rate of incentives available for solar systems. The article concludes with a discussion on implications for the lowincome housing literature, policy, and practice. 


\section{Literature Review}

\subsection{Energy-efficient low-income housing}

In recent years, environmental concerns and the rising cost of energy have prompted a shift towards more energy-efficient homes regardless of end-users' finances. There are major reasons for decision-makers to consider energy-efficient housing for low-income residents. First, sustainable development requires a balanced integration of economic, environmental, and social goals. Nonetheless, environment and climate policy sectors alone are not capable of achieving all of the objectives and thus must work with traditionally siloed policy sectors, such as low-income housing $[11,12]$. Second, due to access to resources and information, public officials are increasingly responsible for taking the initiative to recognize and deploy innovative policies and programs, whether or not such utilities are expressed wants of all citizens [13].

Similarly, empirical evidence suggests that energy and water efficiency significantly reduce the total cost of living for low-income households throughout the building life-cycle $[14,15]$. Lifecycle thinking is particularly consistent with the way LIHTC developments are financed, and research suggests energy-efficient LIHTC units built to high-performance building standards (e.g., ASHRAE 90.1, ASHRAE 90.2) and rating systems (e.g., Energy Star for Homes, LEED, EarthCraft) can be more cost-effective than conventional units for stakeholders and the society as a whole in the long term $[16,17]$. LIHTC-financed housing units are charged a flat rent depending on the Area Median Income (AMI), typically close to 30 percent of household income for gross housing costs, including utilities. Therefore, if a LIHTC tenant's income decreases, they will be spending more than 30 percent on the monthly rent. Resident behavior and rising energy prices can increase utility costs, and the extra amount taken out of residents' monthly income and spent on utilities impacts housing affordability and economic well-being [18,19]. Some LIHTC projects 
convert to market-rate units after the first 15-year compliance period due to lack of resources and funding to replace building systems in need of repair. Life-cycle savings from the adoption of durable energy-efficient building systems could help increase housing affordability, preserve the affordable units, and prevent the relocation of residents at the end of the compliance period [20]. Despite potential benefits, energy-efficient low-income housing units have positive externalities, meaning multiple factors, including split incentives, information lags, and asymmetries, risk aversion, skill shortages, and analytical failures. These externalities can lead to underinvestment in these units in the free market. Thus, government intervention is needed for the efficient distribution of social benefits [21,22]. Although the benefits of energy-efficient building for society as a whole are often larger than the average cost premium to obtain energy certifications, residential developers demand significant price premiums that are likely to affect affordability [23]. For instance, researchers have often reported up to 10 percent sales price premiums associated with energy-efficient single-family units with green building certifications in US cities [24,25]. Empirical studies suggest that financing initiatives highly affect (as much as 100 percent) the adoption of renewable energy generation systems in the residential sector [26]. Low-income housing legislation aimed at promoting sustainability and preserving housing affordability could balance energy-efficiency and renewable energy needs pending the careful assessment of the required levels of incentive and supportive financing mechanisms.

\subsection{Zero-energy buildings}

Built on low-energy building research which dates back to the 1940s, zero-energy buildings have received growing attention in recent years and are being incentivized and mandated in the housing sector to help developed countries, including the US, achieve carbon neutrality [27,28]. Zeroenergy residential buildings use renewable sources of energy to generate enough energy to offset 
the operation-phase energy demand, which normally includes heating, cooling, ventilation, domestic hot water, fixed lighting, plug loads, and elevators. An alternative and/or complementary to on-site renewable energy generation is a utility-scale renewable energy grid, which benefits from scale economies and equalizes local peaks.

In 2010, the European Union (EU) directive on the energy performance of buildings asserted that member states should ensure all new buildings are nearly zero-energy buildings by 31 December 2020 [29]. In 2008, California's long-term energy-efficiency strategic plan adopted energy efficiency goals stating all new residential construction in California will be zero-energy by 2020, which became a mandate in 2018 [30]. Past research concludes that energy use in the operation phase roughly accounts for 70-90 percent of a building's life cycle energy use, showing the significance of zero-energy buildings in mitigating greenhouse gas emissions. Considering the embodied energy of electricity grids, energy savings achieved in the operation of zero-energy buildings is considerably larger than the increase in embodied energy when switching from passive to zero-energy houses [31].

The US Department of Energy (DOE) recognizes builders for leadership in increasing energy efficiency, improving indoor air quality, and making homes zero-energy ready through the Zero Energy Ready Home program [32]. The DOE defines a zero-energy building as "an energyefficient building where, on a source energy basis, the actual annual delivered energy is less than or equal to the on-site renewable exported energy" [33]. Accordingly, delivered energy refers to "any type of energy that could be bought or sold for use as building energy", and exported energy is "on-site renewable energy supplied through the site boundary and used outside the site boundary" [33]. In the DOE's definition, the source energy is composed of the delivered energy, plus the energy consumed in the extraction, processing, and transport of primary fuels plus energy losses 
in thermal combustion and in power generation plants plus energy losses in transmission and distribution to the building site [34]. An implicit assumption in this definition is that zero-energy buildings are not fully autonomous buildings and need to remain connected to existing energy grids that are able to exchange energy with the building. According to this definition, the embodied energy of building materials, construction, and recycling, may or may not be considered in zeroenergy building calculations.

Zero-energy building balance is a condition in which the sum of all generated energy is equal to or higher than the sum of all building energy loads over a period, nominally a month or a year. Load matching refers to the temporal match between load and generation and represents the building's ability to work dynamically, in synergy with the grid. Salom et. al (2011) reviews various load matching indicators [35]. Equations (1) and (2) represent zero-energy building balance, where $e$ and $d$ stand for exported and delivered energy, $g$ and $l$ stand for generation and load, and $w$ and $i$ stand for weighting factor and energy carrier. $E, D, G$, and $L$ stand for weighted exported energy, weighted delivered energy, weighted generation, and weighted load, respectively. Equation (3) represents load matching index, where $F$ is the load matching index, $t$ is the time interval used, e.g. hour, day or month, and $N$ stands for the number of data samples (12 for monthly and 8760 for hourly time interval). For guidance and information on the grid interaction index equation, see Sartori et al. (2012) [36].

$\sum_{i} e_{i} \times w_{e, i}-\sum_{i} d_{i} \times w_{d, i}=E-D \geq 0$

Eq. 1

$\sum_{i} g_{i} \times w_{e, i}-\sum_{i} l_{i} \times w_{d, i}=G-L \geq 0$

Eq. 2

$f_{\text {load }, i}=\frac{1}{N} \times \sum_{\text {year }} \min \left[1, \frac{g_{i}(t)}{l_{i}(t)}\right]$

Eq. 3 
To maximize a zero-energy building's operation at the balance condition over time, the demand should be reduced by the means of energy efficiency, and the supply should be increased by the means of renewable energy systems. Although zero-energy buildings are often designed to achieve energy balance on an annual basis, increasing the generation-load match in smaller time scales using optimized energy storage systems reduces zero-energy buildings' stress on the existing grid, particularly at the times of peak energy demand, and reduces energy waste and carbon-related emissions [37]. Past research has examined different equations and weights to define the zeroenergy building balance, including balances of primary energy, site energy, carbon emissions, and energy cost for different energy systems [38,39]. Data from the International Energy Agency suggest that the percentage of source energy that reaches the final end-user, which describes the overall energy efficiency in the US supply sector, was 67.69 percent in 2010. The DOE definition of zero-energy buildings implies that these buildings should progress the restoration of the remaining 32.31 percent (loss) to the infrastructure system.

The surplus energy generation could be used as a basis to support asymmetric valuations of the energy exchanged between zero-energy buildings and energy grids, pricing the exported energy higher than that of the delivered energy. To export the equivalent of 32.31 percent of the annual load from multi-family buildings would require taking into account the need for large solar systems, installation of which may not currently be feasible based on design requirements and/or space availability in areas with low solar potential. For guidance and information on issues in zeroenergy building, see D'Agostino \& Mazzarella (2019) [34].

\subsection{Cost-benefit analysis and simulation-based risk analysis}

Researchers have examined the feasibility of utilizing renewable energy systems for residential and commercial purposes, while often in isolation [40,41]. The common approach is to evaluate 
the integration of one or more renewable energy systems like solar systems, wind turbines, heat pumps, district heating and cooling into new or existing developments using simulations and calculating the energy payback period or levelized cost of energy in each scenario [42]. Amasyali \& El-Gohary (2018) reviewed past research on data-driven building energy consumption prediction [43]. Some have used simulation software, such as EnergyPlus, HOMER, and TRNSYS, in conjunction with daily or monthly load profile data obtained from study cases. Most studies have focused on a single building and fewer studies have considered multiple developments with similarities and differences. Cost-benefit analyses include multiple non-financial criteria, such as the availability of technology, warranty period, ease of maintenance, required roof or ground area, avoided carbon emissions, and sensitivity analyses include the effect of changing key input variables for project outcomes, such as the effects of the cost of delivered energy, the value of exported energy, the introduction of a carbon tax, and the price of power generation technology. Fewer studies include an assessment of risk and uncertainty (e.g., the occurrence of alternative future events, into financial analysis) and most available studies rely on performing simple financial analyses [44].

As a powerful tool for evaluating the effects of policy decisions, cost-benefit analysis relies on estimates about variables that are not accurately predictable, e.g., future prices, weather patterns, occupant behavior [45]. To effectively contribute to rational decision making, an analysis (e.g., scenario analysis, sensitivity analysis, Monte Carlo simulation) of risks and uncertainties associated with observed data and modeling errors that could change the project outcome and identify the range of possible outcomes should be an integral part of any cost-benefit analysis [44,46-48]. A conundrum about cost-benefit analysis is the choice of discount rate for future costs and benefits of projects. The United States (US) Government recommends deterministic cost- 
benefit models followed by sensitivity analyses and Monte Carlo simulations to perform a full risk analysis of costs and benefits of policy interventions. US Government guidelines for cost-benefit analysis of federal programs have required a discount rate of 7 percent, which is supported by more recent research suggesting discount rates in the range of 6-8 percent $[49,50]$.

The National Renewable Energy Laboratory (NREL) benchmarks average U.S. solar photovoltaic (PV) system installed costs weighted by state installed capacities, accounting for all system and project development costs incurred from the perspective of the developer/installer, including profit in the cost of the hardware, along with the profit the installer/developer receives. According to NREL, residential rooftop systems, ranging from 3-10 kW in size, cost \$2.71 per watt DC (Wdc) or $\$ 3.11$ per watt AC (Wac) in the first quarter of the year 2018. Figure 1 presents the NRELestimated inflation-adjusted national average rooftop system costs in 2018 dollars. The gradual decrease in total cost has resulted from various drivers working simultaneously, including increases in module efficiency, labor productivity, small installer market share, and decreases in supply chain cost, permitting cost, and structural and electrical balance of system commodity pricing. According to the benchmarking analysis, the total cost of residential PV systems has decreased by 4.91 percent, from 2017-2018, and it can be expected that in 2019 and 2020, the total cost per watt DC (Wdc) has decreased to $\sim \$ 2.57$ and $\sim \$ 2.45$, respectively. Since on-site electricity storage systems significantly increase the total cost of installation, the most common approach to zero-energy building, particularly where full retail net metering is not available, is to simply rely on the electricity grid [51]. Additional data and information on residential solar photovoltaics with energy storage systems are available in NREL's installed cost benchmarks [52]. Information on major trends in the U.S. solar industry can be found in the Solar Energy Industries Association's (SEIA) solar market insight reports [53]. 


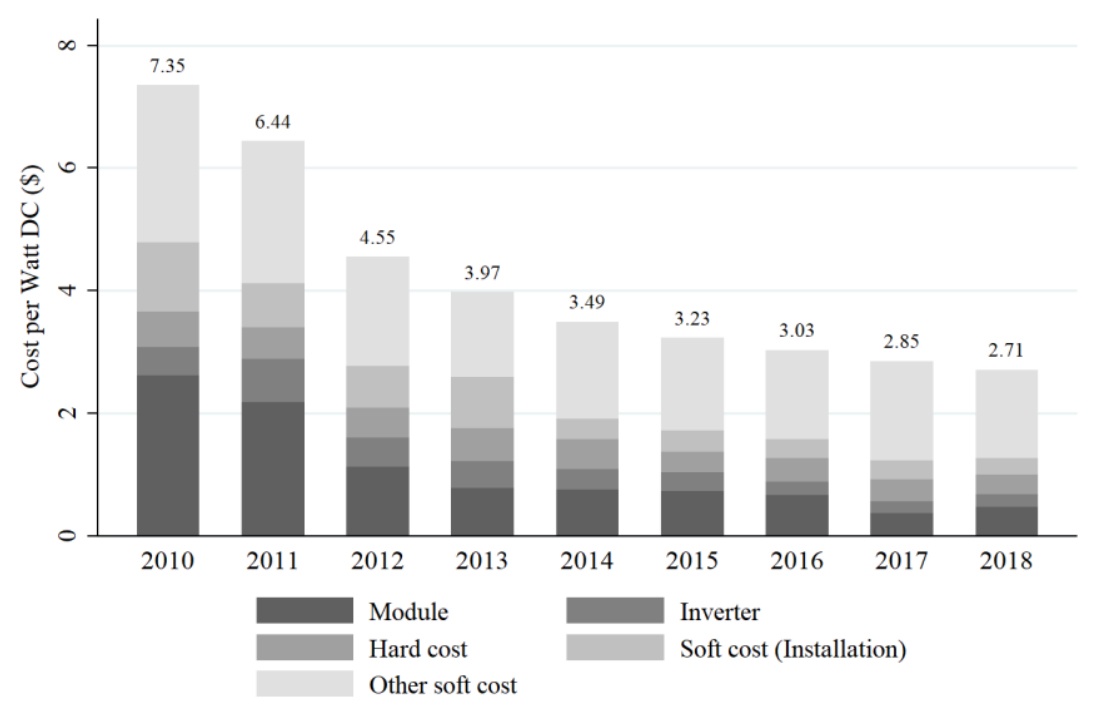

Figure 1 Inflation adjusted residential PV (6.2 kW) system cost from 2010-2018. [54]

\section{Methodology}

\subsection{Analysis framework}

Several US states, including Virginia, have enacted legislation demanding the production of 100 percent of electricity from carbon-free sources by 2050. The flowchart depicted in Figure 2 presents a generalizable framework for analyzing the feasibility of achieving region- or state-wide zero-energy in LIHTC developments. Since the future life-cycle values included in the feasibility analysis of any hypothesized study cases are unknown, the framework relies on values that have the greatest probability of occurring as suggested by historical data and provides reasonable estimates for modeling purposes. The authors apply and validate this framework using empirical data in a proof-of-concept case study to test the study hypothesis and answer the research questions. 


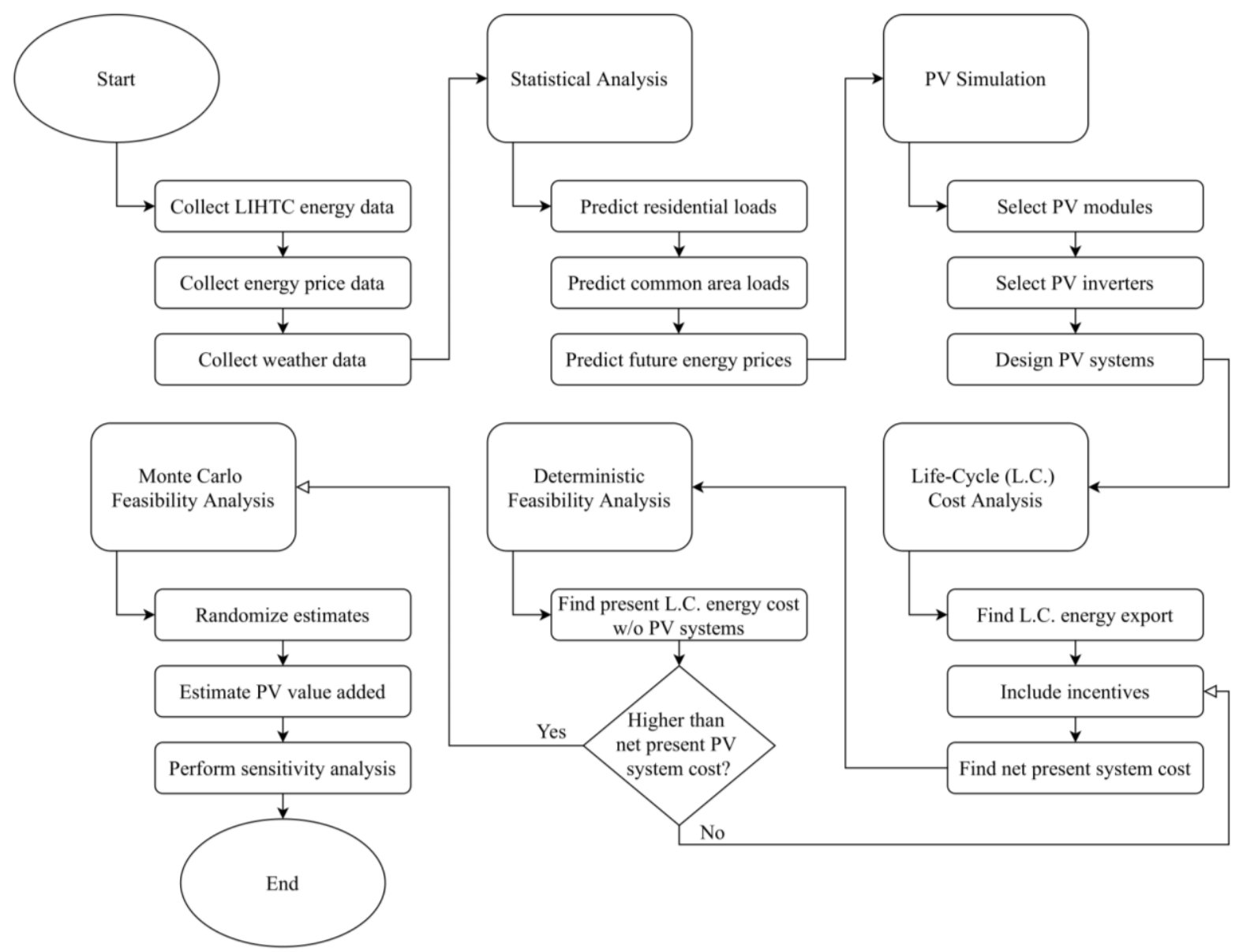

Figure 2 Zero-energy multi-family LIHTC development feasibility analysis framework (created in https://app.diagrams.net)

\subsection{Data collection}

From the LIHTC program's inception in 1987 to 2017, 1,061 multi-family developments including 95,854 apartments have been placed into service in Virginia. On average, each development has 90.43 units ( \pm 72.58 SD). The authors collected longitudinal, apartment-level energy use data on a monthly basis from May 2013 to April 2016 from 310 residential apartments across 15 LIHTC developments. The sample set was large enough to represent all LIHTC apartments built in Virginia with a 5 percent margin of error and a 95 percent confidence interval. Electricity is the only source of energy for all apartments in the sample, and the monthly electricity use data are obtained with residents' consent, support from property managers, and in compliance with XXXX 
institution's Institutional Review Board (IRB). The geographic clusters selected for random energy data sampling were the metropolitan statistical areas (MSAs) of Blacksburg-Christiansburg, Charlottesville, Hampton Roads, Harrisonburg, Kingsport-Bristol, Lynchburg, Richmond, and Washington-Arlington-Alexandria, which are nine of the eleven state MSAs and represent five of the six state climatic divisions defined by the National Oceanic and Atmospheric Administration (NOAA) (Figure 3). In addition to apartment-level monthly electricity use (kWh), the energy use dataset includes the apartments' conditioned floor area, type of construction (e.g., new or renovated), type of occupants (e.g., family or senior), and the apartments' energy-efficiency level as represented by the Home Energy Rating System (HERS) Index.

Developed and maintained by Residential Energy Services Network (RESNET), the HERS Index is the nationally recognized industry standard by which a residential unit's energy efficiency is calculated. A score of 100 is equal to the new construction standard of the current International Residential Code (IRC). A score of 150 means the modeled house is 50 percent less energy efficient than a standard new home. The IRC is upgraded on a three-year cycle, and the LIHTC developments from which energy use data are collected comply with the 2009 UBC, an amended version of the 2009 IRC/IBC. Typically, the amendment process creates a lag in adoption and enforcement. Therefore, when the sample apartments were being built from 2011-2013, the 2009 UBC was being enforced. Common areas (e.g., lobby, hallway, manager's office, gym, elevator) are excluded from the main analysis due to high levels of variability in space programming and energy use, which reduce generalizability. Common areas in the building can be treated as one large unit that is sub-metered and billed to the developer often based on commercial energy price rates. Common areas' energy information is available for benchmarking purposes at the Lawrence Berkeley National Lab's Building Performance Database (BPD) (https://bpd.lbl.gov), or online 
energy benchmarking services (www.wegowise.com). The authors obtained data of the NOAAdefined climatic divisions from the National Solar Radiation Database (NSRDB) weather files (https://nsrdb.nrel.gov), and collected data of state-wide average retail price of electricity for residential and commercial use from the Energy Information Administration (EIA) website (www.eia.gov) of the US DOE.

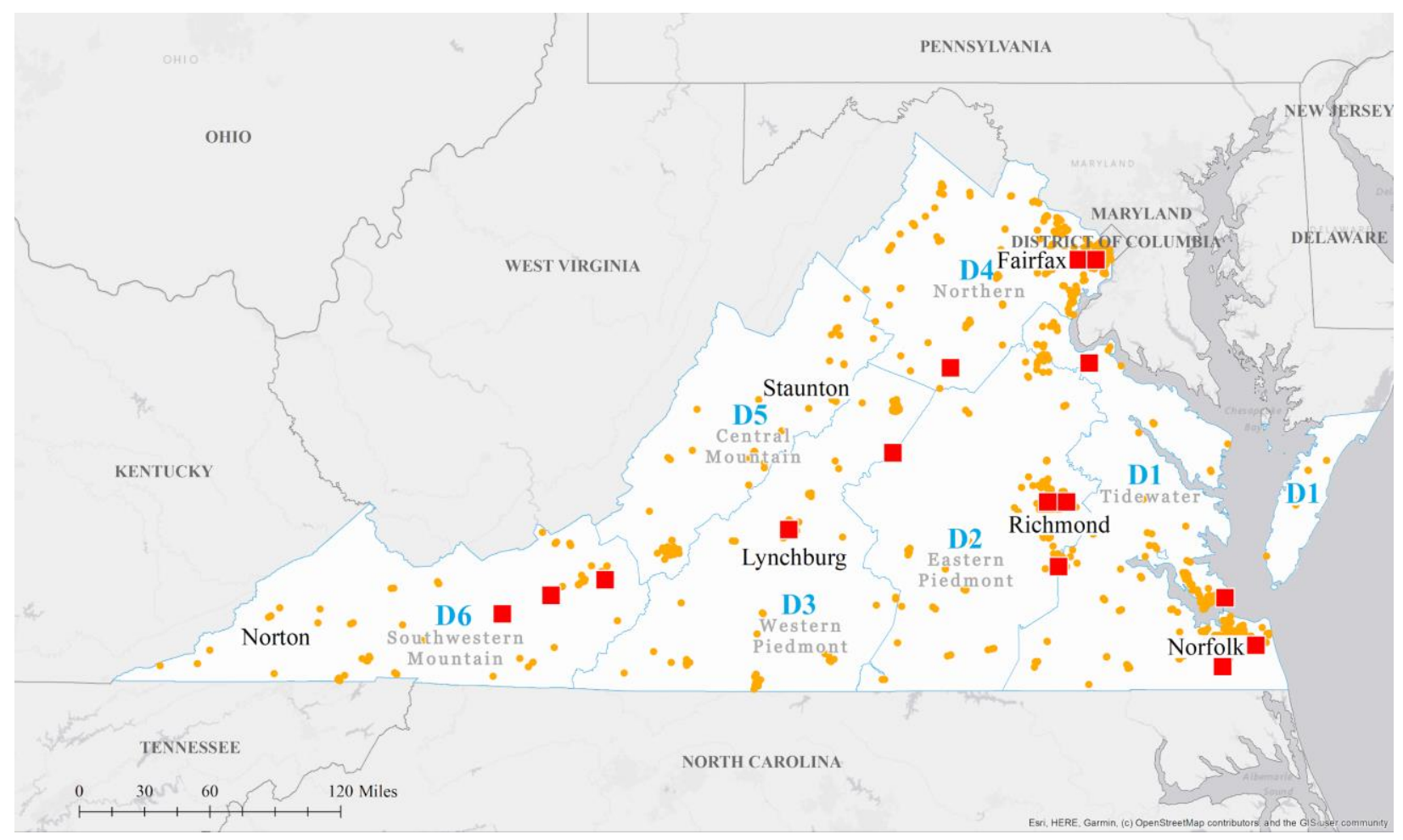

Figure 3 State climatic divisions and sampled (red squares) and existing (orange dots) LIHTC developments

\subsection{Statistical analysis of loads}

Using longitudinal data obtained from the geographical cluster sampling of LIHTC developments in Virginia, the authors estimate the energy load of residential apartments of the study case based on a multivariate regression model created in Stata 14.0 of StataCorp LLC (Eq. 4). The regression analysis provides the mean load for a residential apartment of a given size in a given climatic division, month, and year. The regression equation takes the basic form: 


$$
\operatorname{Sqrt}\left(L_{i j k l}\right)=A_{i} \alpha+H_{i} \beta+R_{i} \gamma+S_{i} \delta+\sum_{j=1}^{6} C_{i, j} \theta_{i, j}+\sum_{k=1}^{12} M_{i, k} \lambda_{i, k}+\sum_{l=1}^{3} Y_{i, l} \mu_{i, l}+\varepsilon \quad \text { Eq. } 4
$$

where $\operatorname{Sqrt}\left(L_{i j k l}\right)$ is the dependent variable, operationalized as the square root of energy load of LIHTC apartment $i$ in climatic division $j$ in month $k$ in year $l$. The continuous variables $A_{i}$ and $H_{i}$ are the size (in square feet) and HERS score of apartment $i$, respectively. The binary variables $R_{i}$ and $S_{i}$ denote whether the apartment $i$ belongs to a renovation or new construction development and whether the apartment $i$ is occupied by senior or family households, respectively. The binary variables $C_{j}, M_{k}$, and $Y_{l}$ denote the fixed effects of climatic division, month, and year of energy load. $\alpha, \beta, \gamma$, and $\delta$ are unknown coefficients and $\theta_{i, j}, \lambda_{i, k}, \mu_{i, l}$ are vectors of unknown coefficients. The square-root transformation improves residual normality, reduces heteroskedasticity, and increases goodness-of-fit. The authors used Variance Inflation Factors (VIFs) to inspect for and avoid multicollinearity. Since margins obtained from the model represent conditional means of energy load, the total energy load of all apartments in a building is estimated by summing the predicted loads for all given apartment sizes multiplied by the number of apartments of those sizes in the building. Compared to conventional deterministic load forecasting based on a predefined set of load values, the adopted statistical approach can reduce uncertainty (e.g., variability whose distribution of values cannot be defined) using empirical data. The risk (e.g., variability whose distribution of values can be defined) is assessed using simulation-based risk analysis, also known as Monte Carlo analysis. Once residential loads in the reference location (Richmond, VA) are predicted, the energy use in $\mathrm{kWh}$ per degree day is used to estimate weathernormalized loads in other climatic divisions. The authors predict the annual average retail price of electricity based on a simple linear regression model. For guidance and more information on available electricity price forecasting methods, see Weron (2014) [55]. 


\subsection{Study case and PV system simulation}

The reference study case is a new LIHTC project in Richmond, VA, built to comply with the 2009 IRC building code, the same code version with which the sampled buildings comply. The average number of units per LIHTC application in the state from 2011-2020 is 67 ( \pm 40 SD). The study case is a 60-unit residential building composed of equal numbers of small (693 sf), medium (910 sf), and large (1087 sf) units. The PV system is designed so that the energy exported to the existing utility grid during the first 30 years of operation simply exceeds the energy delivered to the building from the grid on an annual basis, without applying any weighting factors. Therefore, the analysis relaxes the need to fully offset the primary energy loss in the infrastructure in favor of minimizing the required rooftop area. The authors use the System Advisor Model (SAM) software to design, simulate, and estimate the energy performance of distributed photovoltaic systems for individual residential apartments in the study case.

The National Renewable Energy Laboratory (NREL) of the US DOE developed SAM as free techno-economic software to help project managers and engineers, policy analysts, technology developers, and researchers calculate performance and financial metrics of renewable energy projects. SAM is an open-source project, allowing researchers to access its publicly available codes, explore its algorithms, and add models and enhancements to all projects. Reference manuals describing the model algorithms are available at the NREL's website (https://sam.nrel.gov). Blair et al. (2018) provides a detailed description of SAM and Gilman et al. (2018) presents the photovoltaic performance model algorithm [56,57]. All the required weather information - hourly, or sub-hourly with up to one-minute time resolution - for the selected cities is obtained based on the closest weather station data available in the current version of the National Solar Radiation Database (NSRDB) and added to the software. 


\subsection{Feasibility analysis}

The discounted cash flow (DCF) analysis tests whether the net present cost of the implementation of rooftop residential solar systems to achieve zero-energy LIHTC buildings would be lower than the discounted present energy cost of an otherwise identical building with no renewable energy generation systems. The first approach to feasibility analysis is to obtain the base case deterministic Net Present Value (NPV) of investment in a solar system that its generated energy exceeds the energy load of the reference building during its life-cycle. The NPV is obtained from subtracting the net present cost of the implementation of rooftop residential PV systems from the discounted present cost of the future cash flow of energy of the same building without renewable energy generation systems at a 7 percent discount rate (see the previous discussion on DOE discount). The authors examine cash flow periods of both 15 years and 30 years which reflect typical LIHTC construction loan periods. Since the values included in such an analysis can vary on a random basis, the authors perform a simulation-based risk analysis to account for risk and uncertainty. The Monte Carlo sampling method generates multiple probable outcomes for energy load, energy generation, and energy price based on historical data. Once the means and standard deviations of annual values of the three independent functions are predicted from statistical regression, the inverse cumulative distribution with random probabilities corresponding to the normal distribution of the predicted values is estimated and included in a single Monte Carlo simulation. The advantage of this method over the deterministic analysis is that it provides estimates of the NPV's mean, standard error, estimation error, and risk of loss (i.e., negative NPV). Iterations of the simulation are treated as a sample of all possible values of the real NPV, and the true mean can be estimated within a specific confidence interval and compared using the two-sample t-test to reject the null hypothesis (e.g., there is no statistically significant difference between life-cycle cost savings from the solar system 
implementation and the life-cycle cost of energy of the project without the solar system). The current results are based on 15,000 iterations of the simulation, which ensures, on a gross estimation basis, that the obtained statistics' error margins are less than 2 percent.

\section{Results}

\subsection{Load profiles}

Table 1 presents location, weather characteristics, and unit of measurement of six major cities, each located in one of the six NOAA-defined climatic divisions in Virginia. These major cities are selected for financial analysis to illustrate how benefits and costs of investment in zero-energy LIHTC projects vary across the state. Since degree days in each city can change each year, the mean values for 2013-16 corresponding to the years of sample data collection are chosen to predict energy loads. Table 2 presents descriptive statistics of historical data for state-wide retail prices of electricity for residential use in Virginia from 1990 to 2018. City-specific mean retail prices of electricity are used for financial analysis. Table 3 introduces descriptive statistics of the sample data.

Table 1 Climatic division characteristics

\begin{tabular}{llllllll}
\hline & Division-1 & Division-2 & Division-3 & Division-4 & Division-5 & Division-6 & Unit \\
\hline Selected city & Norfolk & Richmond & Lynchburg & Fairfax & Staunton & Norton & - \\
Latitude & 36.8508 & 37.5407 & 37.4138 & 38.8462 & 38.1496 & 36.9334 & ${ }^{\circ} \mathrm{N}$ \\
Longitude & -76.2859 & -77.4360 & -79.1422 & -77.3064 & -79.0717 & -82.6290 & ${ }^{\circ} \mathrm{W}$ \\
Global horizontal & 4.50 & 4.08 & 4.44 & 4.27 & 4.44 & 4.28 & $\mathrm{kWh} / \mathrm{m}^{2} / \mathrm{day}$ \\
Direct normal & 5.01 & 4.36 & 4.88 & 4.54 & 4.84 & 4.51 & $\mathrm{kWh} / \mathrm{m}^{2} / \mathrm{day}$ \\
Diffuse horizontal & 1.60 & 1.60 & 1.63 & 1.69 & 1.71 & 1.75 & $\mathrm{kWh} / \mathrm{m}^{2} / \mathrm{day}$ \\
Average temperature & 14.50 & 14.90 & 12.80 & 11.80 & 11.10 & 10.80 & ${ }^{\circ} \mathrm{C}$ \\
Average wind speed & 3.60 & 0.80 & 0.10 & 1.90 & 0.30 & 0.10 & $\mathrm{~m} / \mathrm{s}$ \\
2013 degree days & 5201 & 5440 & 5509 & 5920 & 5958 & 5639 & ${ }^{\circ} \mathrm{F}$ \\
2014 degree days & 5235 & 5502 & 5625 & 6027 & 6102 & 5766 & ${ }^{\circ} \mathrm{F}$ \\
2015 degree days & 5063 & 5225 & 5254 & 5722 & 5617 & 5235 & ${ }^{\circ} \mathrm{F}$ \\
2016 degree days & 5296 & 5324 & 5313 & 5753 & 5683 & 5434 & ${ }^{\circ} \mathrm{F}$ \\
Mean 2013-16 degree days & 5198.75 & 5372.75 & 5425.25 & 5855.50 & 5840.00 & 5518.50 & ${ }^{\circ} \mathrm{F}$ \\
\hline
\end{tabular}

Table 2 Descriptive statistics of price of residential electricity 


\begin{tabular}{llllll}
\hline Variable & Description & Mean & Std. Dev. & Min & \multicolumn{1}{c}{ Max } \\
\hline Electricity price & Yearly average retail price of electricity (1990-2018) & 8.976207 & 1.630367 & 7.25 & 11.73 \\
Year & Year & 2004 & 8.514693 & 1990 & 2018 \\
\hline
\end{tabular}

Table 3 Descriptive statistics of energy use

\begin{tabular}{lllllll}
\hline Variable & Description & Mean & Std. Dev. & Min & Max & $\mathrm{P}^{1}$ \\
\hline Load & Monthly load of electricity in kWh & 543.7161 & 303.7686 & 4 & 2930 & \\
Sqrt. load & Square root of monthly load in kWh & 22.48242 & 6.185601 & 2 & 54.12947 & \\
Residential area & Residential unit floor area in square foot & 899.788 & 232.0067 & 595 & 1774 & $0.3452^{* * *}$ \\
HERS & HERS score of residential unit & 68.05397 & 10.62989 & 15 & 98 & 0.0043 \\
Rehabilitation & Rehabilitation (1) or new construction (0) & 0.5807464 & 0.4934585 & 0 & 1 & $-0.1249^{* * *}$ \\
Senior living & Senior living (1) or family living (0) & 0.4095745 & 0.4917767 & 0 & 1 & -0.0058 \\
Climate id & National Weather Service climate division id & 2.552407 & 1.684382 & 1 & 6 & $-0.1568^{* * * *}$ \\
Month & Month of electricity use & 6.431897 & 3.429335 & 1 & 12 & $-0.1943^{* * *}$ \\
Year & Year of electricity use & 2014.297 & 0.9548647 & 2013 & 2016 & $0.1056^{* * *}$ \\
\hline
\end{tabular}

1. P denotes uncontrolled Pearson Correlation Coefficient of dependent variables and electricity use

Table A1 presents the simple linear regression analysis of state-wide retail prices of electricity for residential use in Virginia. On average, the nominal retail price of residential electricity in Virginia has annually increased by 0.18 cents/kWh from 1990-2018 (Fig A1). When adjusting the price using the Consumer Price Index (CPI) of electricity for urban consumers in US cities, the real price of electricity has, on average across the US, decreased by 0.30 percent per year during the same period [58]. Whether this descending trend is going to remain in place is not quite clear, while an increasing trend in the price means PV system users would accrue more financial benefits than initially estimated. The US EIA has developed three different scenarios, suggesting that the national average price of 10.53 cents/kWh in 2018 can range anywhere from $9.7-11.6$ cents/kWh in 2050 depending on economic growth, oil and gas resource prices, and renewable energy generating technology adoption rate [59]. These scenarios are considered in the current feasibility study.

Table 4 presents the conditional mean multivariate regression model of electricity use (the leftmost column) and three quantile regression models from the same data and variables on the right, representing energy load at the first, second, and third quartiles. Nearly all the variables are statistically significant at $\mathrm{p}<0.01$ and, the main model represents about 41.4 percent of the 
variability of energy load around the mean. The remaining unexplained variability can be attributed to the impacts of occupant behavior, variations in electrical appliances, and microclimatic factors, which have been extensively studied in the literature [60-63].

According to the conditional mean model and holding all other variables constant at the mean levels, each additional square foot of residential unit area increases energy load by $\sim 0.048 \mathrm{kWh}$ per month. The model suggests that residential units in rehabilitation developments have, on average, $\sim 227.52 \mathrm{kWh}$ per month less energy load than otherwise identical units in new construction developments. In addition, units occupied by senior households have, on average, $\sim 1,288.57 \mathrm{kWh}$ per month more energy load than otherwise identical units occupied by family households.

Table 4 Multivariate regression model of electricity use (Dependent variable: square root of electricity use) ${ }^{1}$

\begin{tabular}{llllll} 
Coef. & Std. Err. & P $>t$ & 25th Perc. Coef. & 50th Perc. Coef. & 75th Perc. Coef. \\
\hline
\end{tabular}




\begin{tabular}{|c|c|c|c|c|c|c|}
\hline Residential area & 0.0069323 & 0.0003169 & 0.000 & $0.0064999 * * *$ & $0.0060889 * * *$ & $0.0065996^{* * *}$ \\
\hline Rehabilitation & -0.4769924 & 0.1506556 & 0.002 & $1.4119500 * * *$ & $-0.3180811 *$ & -1.3594700 *** \\
\hline Senior living & 1.135154 & 0.1968914 & 0.000 & $2.4538260 * * *$ & $1.3024960 * * *$ & 0.3886456 \\
\hline HERS & 0.0679031 & 0.0053108 & 0.000 & $0.0305185^{* * *}$ & $0.0383766^{* * *}$ & $0.0797102 * * *$ \\
\hline Division_2 & -2.887875 & 0.1665886 & 0.000 & $-2.8858520 * * *$ & $-2.9138500 * * *$ & $-2.6076770 * * *$ \\
\hline Division_3 & 0.7784545 & 0.281223 & 0.006 & $1.8117380 * * *$ & $0.6446663 * *$ & $0.7666906^{*}$ \\
\hline Division_4 & -5.08997 & 0.234813 & 0.000 & $-3.1304970 * * *$ & $-4.2182950 * * *$ & $-4.7952220 * * *$ \\
\hline Division_6 & -2.119919 & 0.2131439 & 0.000 & -0.3015351 & $-1.5618940 * * *$ & $-2.5685620 * * *$ \\
\hline Year_2014 & 0.7895158 & 0.1521175 & 0.000 & $0.5397313 * * *$ & $0.6422507 * * *$ & $0.9825435^{* * *}$ \\
\hline Year_2015 & 0.5985464 & 0.1565756 & 0.000 & $0.3706764 * *$ & $0.5375932 * * *$ & $0.7723584 * * *$ \\
\hline Year_2016 & -0.5726827 & 0.2345463 & 0.015 & $-1.2468680 * * *$ & $-0.6365490 * *$ & -0.1586213 \\
\hline Month_2 & -0.7780375 & 0.2689897 & 0.004 & $-0.8079312 * *$ & $-0.7477670 * * *$ & $-0.9516986^{* *}$ \\
\hline Month_3 & -3.267251 & 0.269671 & 0.000 & $-3.3230600 * * *$ & $-3.3488190 * * *$ & $-3.4724800 * * *$ \\
\hline Month_4 & -7.298903 & 0.2697913 & 0.000 & $-7.2202860 * * *$ & $-7.4866920 * * *$ & $-7.9802690 * * *$ \\
\hline Month_5 & -8.170684 & 0.2597029 & 0.000 & $-8.6665310 * * *$ & $-8.3186270 * * *$ & -8.5421940 *** \\
\hline Month_6 & -7.294836 & 0.2751729 & 0.000 & $-8.1423060 * * *$ & $-7.5449440 * * *$ & -7.4053190 *** \\
\hline Month_7 & -6.260478 & 0.2759217 & 0.000 & $-7.1655020 * * *$ & $-6.2866500 * * *$ & $-6.3571220 * * *$ \\
\hline Month_8 & -6.804348 & 0.2768418 & 0.000 & $-7.5921900 * * *$ & $-6.9534360 * * *$ & $-6.9179430 * * *$ \\
\hline Month_9 & -7.970385 & 0.2775862 & 0.000 & $-8.5779890 * * *$ & $-8.1719000 * * *$ & $-8.2824710 * * *$ \\
\hline Month_10 & -7.916289 & 0.2778584 & 0.000 & $-8.2107210 * * *$ & $-8.0144990 * * *$ & $-8.5655400 * * *$ \\
\hline Month_11 & -5.411357 & 0.2781303 & 0.000 & $-5.5206710 * * *$ & $-5.3851030 * * *$ & -5.7131440 *** \\
\hline Month_12 & -2.514067 & 0.2783284 & 0.000 & $-2.7976880 * * *$ & $-2.3983750 * * *$ & $-2.5310830 * * *$ \\
\hline _cons & 18.3616 & 0.6047202 & 0.000 & $16.7306100 * * *$ & $20.7209300 * * *$ & $21.4468200 * * *$ \\
\hline Obs & 7,480 & & & 7,480 & 7,480 & 7,480 \\
\hline Pseudo $\mathrm{R}^{2}$ & & & & 0.2486 & 0.2624 & 0.2607 \\
\hline Adjusted $\mathrm{R}^{2}$ & 0.4135 & & & & & \\
\hline Root MSE & 4.6783 & & & & & \\
\hline
\end{tabular}

Figure 4 depicts the predicted energy load (left) and residuals (right) for each observation. Together, the regression models and the scatter plots suggest uncontrolled variables have large impacts on energy load in LIHTC apartments. Obtained from the conditional mean model, Figure 5 shows the predicted correlation of HERS score with monthly energy load with a 95 percent confidence interval, alluding to the practical significant role of energy-efficiency measures in reducing the operation phase energy use and carbon emissions. Holding all variables at the mean, each one-unit change in HERS score changes energy load by $\sim 4.61 \mathrm{kWh}$ per month. 

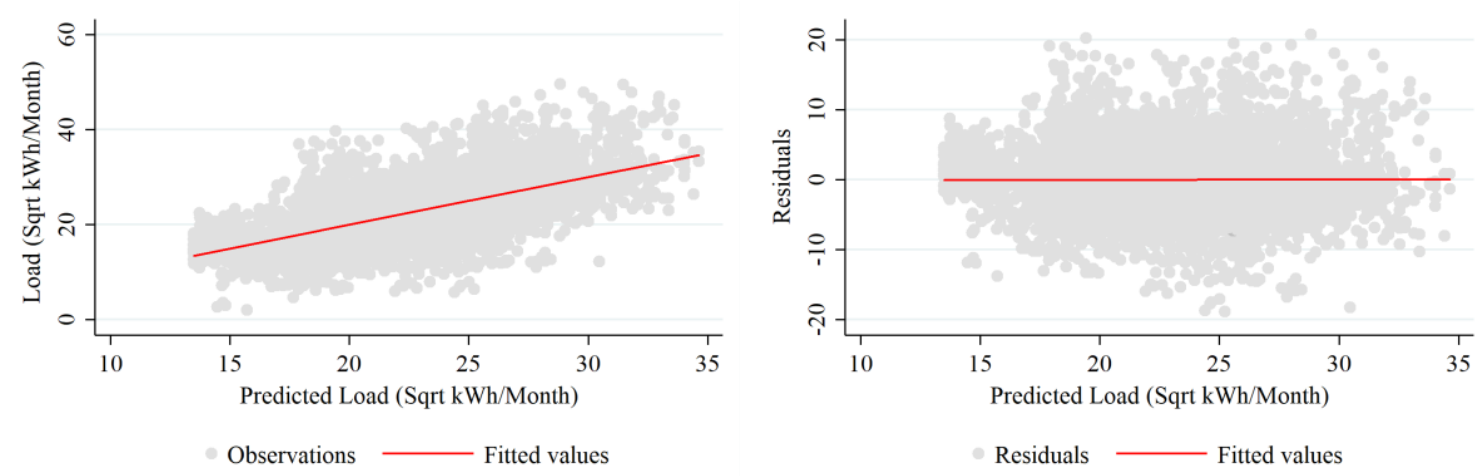

Figure 4 Post-estimated diagnostics of multivariate regression model

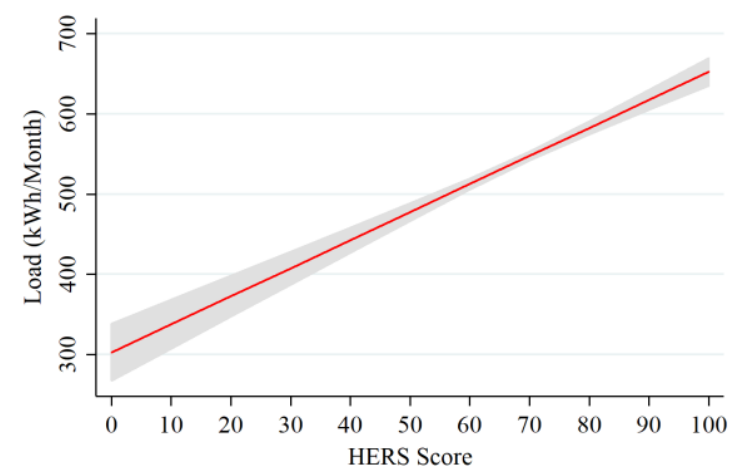

Figure 5 Predicted correlation of monthly load with HERS score with 95 percent confidence interval

Figure 6 illustrates impacts of HERS score, apartment size, and uncontrolled variables on annual energy load of apartments occupied by family households in new construction developments in the reference location, Richmond, VA. The low-, median-, and high-intensity categories refer to the predicted load values obtained from the three quantile regressions presented in Table 4. Similarly, HERS and unit size categories correspond to the first, second, and third quartiles of the corresponding variables. Table A2 presents the mean loads of new family-occupied apartments with median unit size (910 sf) and median HERS score (66) in the year 2013. The data suggest that the mean load of common areas in a 39-unit LIHTC building in the reference location is 113.71 $\mathrm{kWh}$ per month per unit. 


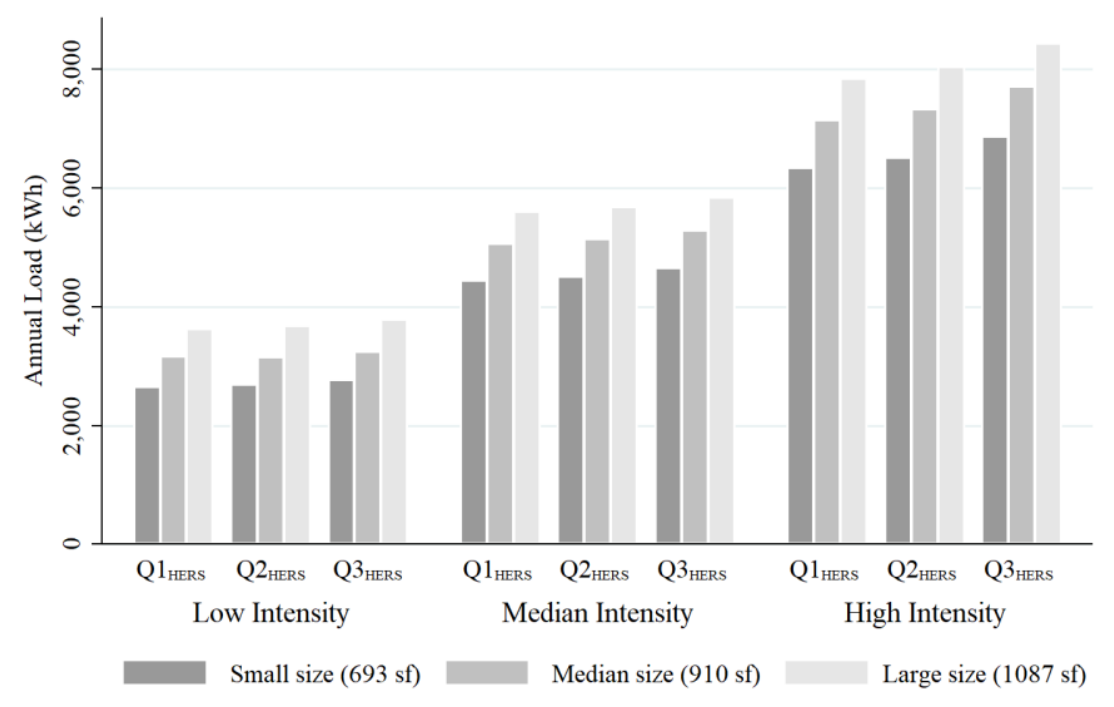

Figure 6 Estimated annual load based on the quartiles of load, unit size, and HERS score in Richmond, VA

\subsection{PV system simulation}

Table 5 and Table 6 present the selected PV module and inverter specifications currently available in the market and the design characteristics of the PV system at the reference location. The energy generated by the system exceeds the annual energy load of a new family-occupied apartment at the median unit size and the median HERS score during the first 30 years of operation. The annual balance partially restores energy loss in the infrastructure system, but to restore all the estimated energy loss ( $\sim 32.31$ percent $)$ discussed previously, each apartment’s array size must increase from $6.5 \mathrm{~kW}(\mathrm{dc})$ to $7 \mathrm{~kW}(\mathrm{dc})$, which increases each module area from $28 \mathrm{~m}^{2}$ to $42 \mathrm{~m}^{2}$. The $0.5 \mathrm{~kW}$ increase in capacity and 50 percent increase in area can increase the investment profit but may not be practical due to limited rooftop space on the 2 -story multi-family building. Figure 7 shows a monthly pattern of energy generation and load in the reference location. 
Table 5 Selected photovoltaic module and inverter characteristics for all climatic divisions in Virginia

\begin{tabular}{llllll}
\hline PV module & Value & Unit & Inverter & Value & Unit \\
\hline Company & LG Electronics & - & Company & Fronius USA & Galvo 1.5-208-240 \\
Model & LG250N8K-G4 & - & Model & 2500 & W(ac) \\
Material & Mono-c-Si & - & Max AC power & 2619.470215 & W(dc) \\
Bifacial & No & - & Max DC power & 16.735605 & W(dc) \\
Standard testing conditions & 250.217 & $\mathrm{~W}(\mathrm{dc})$ & Day power consumption & 0.75 & W(ac) \\
Utility-scale testing conditions & 231.9 & $\mathrm{~W}(\mathrm{dc})$ & Night power consumption & 240 & V(ac) \\
Max power & 250.217 & $\mathrm{~W}(\mathrm{dc})$ & Nominal AC voltage & 440 & V(dc) \\
Voltage at max power & 25.30 & $\mathrm{~V}(\mathrm{dc})$ & Max DC voltage & 7.937789 & A(dc) \\
Current at max power & 9.89 & $\mathrm{~A}(\mathrm{dc})$ & Max DC current & 100 & V(dc) \\
Length & 1.30 & $\mathrm{~m}$ & Min MMPT DC voltage & 440 & $\mathrm{~V}(\mathrm{dc})$ \\
Width & 0.98 & $\mathrm{~m}$ & Max MMPT DC voltage & & \\
\hline
\end{tabular}

Table 6 System characteristics in Richmond, VA

\begin{tabular}{|c|c|c|c|c|c|}
\hline Parameter & Value & Unit & Parameter & Value & Unit \\
\hline Number of inverters & 2 & & Max DC voltage & 440 & $\mathrm{~V}(\mathrm{dc})$ \\
\hline Total number of modules & 22 & & Min MPPT voltage & 100 & $\mathrm{~V}(\mathrm{dc})$ \\
\hline Total number of strings & 2 & & Max MPPT voltage & 440 & $\mathrm{~V}(\mathrm{dc})$ \\
\hline Total module area & 28 & $\mathrm{~m}^{2}$ & Average annual soiling loss & 5 & $\%$ \\
\hline $\mathrm{DC}$ to $\mathrm{AC}$ ratio & 1.10 & & Total DC power loss & 4.44 & $\%$ \\
\hline Desired array size & 6.5 & $\mathrm{~kW}(\mathrm{dc})$ & $\mathrm{AC}$ wiring loss & 1 & $\%$ \\
\hline Nameplate DC capacity & 5.505 & $\mathrm{~kW}(\mathrm{dc})$ & Annual DC degradation rate & 0.5 & $\%$ \\
\hline Total AC capacity & 5.0 & $\mathrm{~kW}(\mathrm{dc})$ & Tilt and azimuth & 20,180 & Degree \\
\hline Total inverter DC capacity & 5.239 & $\mathrm{~kW}(\mathrm{dc})$ & Ground coverage ratio & 0.3 & GCR \\
\hline
\end{tabular}

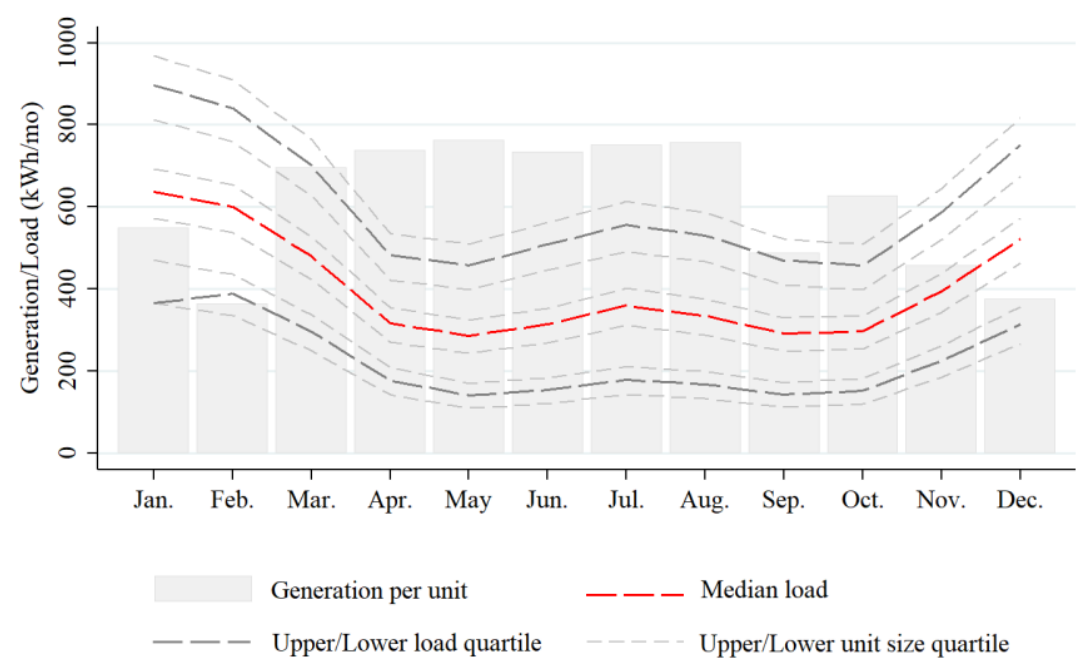

Figure 7 Energy generation per unit and load quartiles in Richmond, VA

Figure 8 depicts the result of applying the same module, inverter, and design to the same mediansize, median-HERS, median-load apartment in the state's six climatic divisions. The divisions 16 are ordered from left to right in each month and the values belong to the first year of operation. The red bars represent negative monthly balance, e.g., generation shortage to fully offset the energy load. Table 7 presents the estimated cost of installation of the designated PV system in the year 
2020. According to the NREL's benchmarking analysis, the national average cost of residential PV systems has decreased by $4.91 \%$, from 2017-2018, and it can be expected that in the year 2020 , the total cost per watt DC (Wdc) is approximately $\$ 2.45$. For the purpose of financial analysis, the total cost per watt DC of $\$ 2.49$ is uniformly applied to all climatic divisions.

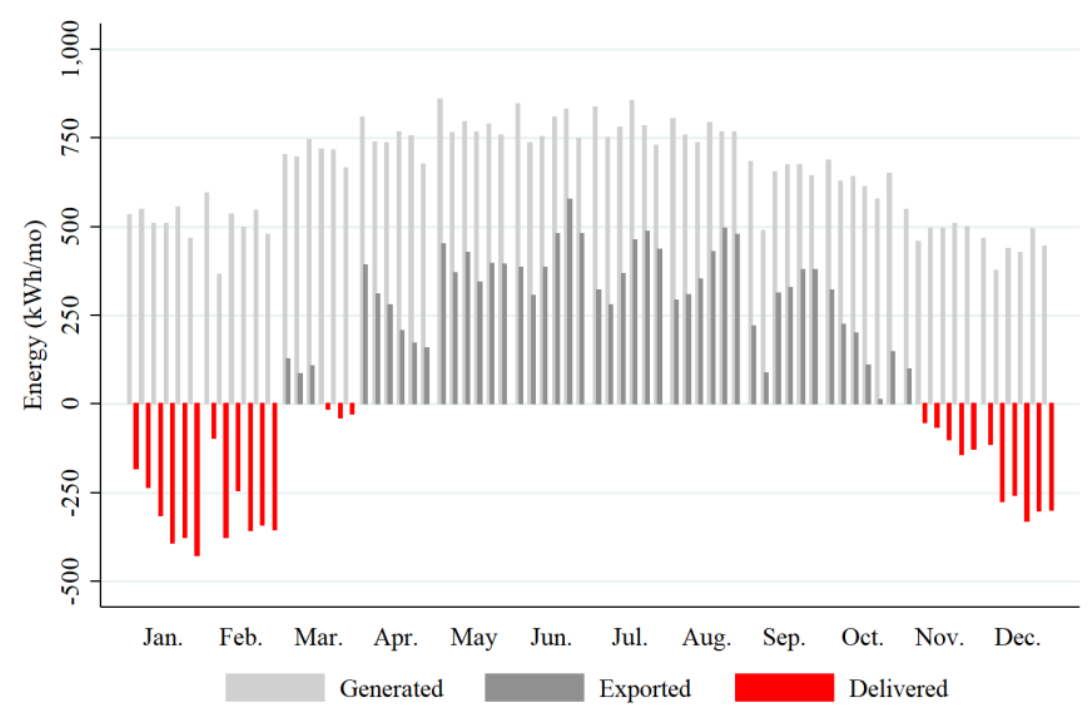

Figure 8 Estimated generated, exported, and delivered energy of median unit in six divisions Table 7 Cost of system installation for one residential unit

\begin{tabular}{lll}
\hline Item & Unit Cost $(\$ / \mathrm{Wdc})$ & Total Cost $(\$)$ \\
\hline Direct capital costs & & \\
$\quad$ Module & $\$ 0.45$ & $\$ 2,475.00$ \\
$\quad$ Inverter & $\$ 0.14$ & $\$ 700.00$ \\
$\quad$ Balance of system equipment & $\$ 0.36$ & $\$ 1,980.00$ \\
$\quad$ Installation labor & $\$ 0.4$ & $\$ 2,200.00$ \\
$\quad$ Installer margin and overhead & $\$ 1$ & $\$ 5,500.00$ \\
Total direct cost & & $\$ 12,855.00$ \\
$\quad$ Indirect Capital Costs & & $\$ 550.00$ \\
$\quad$ Permitting and environmental studies & & $\$ 276.38$ \\
$\quad$ Sales tax (0.043 in VA) & $\$ 2.49$ & $\$ 826.38$ \\
$\quad$ Total indirect cost & & $\$ 13,681.38$ \\
$\quad$ Total installed cost & &
\end{tabular}

\subsection{Discounted cash flow analysis}

The study case is a two-story 60-unit LIHTC building comprising small (693 sf), medium (910 sf), and large (1087 sf) apartments in equal numbers. The total residential load is estimated from the sum of predicted loads for all given apartment sizes multiplied by the number of apartments of 
each size (20) in the building. Table 8 summarizes the assumptions and results of the 15 -year and 30-year deterministic DCF analyses for Richmond, VA, including values from the stabilization year (2021) and the last year of cash flow periods. The year 2020 federal solar tax credit, which allows the owners to deduct 26 percent of the cost of installing a solar energy system from federal income taxes of that same year, is included in both analyses. State-, locality-, or LIHTC-related incentives are not considered. To simplify the calculations, the NPV of investment for the 3 individual apartment sizes (called sample) are first obtained and then multiplied by 20 . 
Table 8 Deterministic DCF analysis for Richmond, VA

\begin{tabular}{|c|c|c|c|c|c|}
\hline \multicolumn{2}{|l|}{ Items / Assumptions } & \multicolumn{2}{|c|}{ 15-Year Cash Flow } & \multicolumn{2}{|c|}{ 30-Year Cash Flow } \\
\hline \multicolumn{6}{|l|}{ Items } \\
\hline Load (kWh/yr) & Year 2021 & DPV & Year 2035 & DPV & Year 2050 \\
\hline Small unit load (693 sf) & $5,212.16$ & & $5,212.16$ & & $5,212.16$ \\
\hline Median unit load (910 sf) & $6,071.16$ & & $6,071.16$ & & $6,071.16$ \\
\hline Large unit load (1087 sf) & $6,771.83$ & & $6,771.83$ & & $6,771.83$ \\
\hline Total load & $18,055.15$ & & $18,055.15$ & & $18,055.15$ \\
\hline Total cost of energy without $\mathrm{PV}^{1}$ & $(\$ 2,163.36)$ & $(\$ 21,377.95)$ & $(\$ 2,610.28)$ & $(\$ 30,706.96)$ & $(\$ 3,089.12)$ \\
\hline \multicolumn{6}{|l|}{ PV system energy generation $(\mathrm{kWh} / \mathrm{yr})$} \\
\hline Generation per unit & 7,303 & & $6,802.24$ & & 6,303 \\
\hline Total generation & $21,908.73$ & & $20,406.72$ & & $18,908.43$ \\
\hline Total export & $5,911.21$ & & $4,409.20$ & & 853.28 \\
\hline Total value of exported energy ${ }^{2}$ & $\$ 461.73$ & $\$ 3,791.27$ & $\$ 339.97$ & $\$ 4,642.35$ & $\$ 145.99$ \\
\hline \multicolumn{6}{|l|}{ PV system cost of financing and operating } \\
\hline Debt balance per unit & $\$ 10,040.80$ & & $\$ 0.00$ & & $\$ 0.00$ \\
\hline Interest payment per unit & $(\$ 688.80)$ & $(\$ 3,418.53)$ & $(\$ 49.04)$ & $(\$ 5,080.33)$ & $(\$ 31.58)$ \\
\hline Principal payment per unit & $(\$ 207.35)$ & $(\$ 6,239.27)$ & $(\$ 980.82)$ & $(\$ 3,366.48)$ & $(\$ 631.57)$ \\
\hline Maintenance cost per unit & $(\$ 110.00)$ & $(\$ 1,161.28)$ & $(\$ 155.43)$ & $(\$ 1,770.87)$ & $(\$ 225.10)$ \\
\hline Insurance cost per unit & $(\$ 69.00)$ & $(\$ 728.44)$ & $(\$ 97.50)$ & $(\$ 1,110.82)$ & $(\$ 141.20)$ \\
\hline Total cost of financing and operating & $(\$ 3,225.45)$ & $(\$ 34,642.56)$ & $(\$ 3,848.35)$ & $(\$ 33,985.52)$ & $(\$ 3,088.37)$ \\
\hline \multicolumn{2}{|c|}{ Net present cost of PV system for sample (3 units) ${ }^{3}$} & $(\$ 30,851.28)$ & & $(\$ 29,343.20)$ & \\
\hline \multicolumn{2}{|l|}{ NPV of investment for sample ( 3 units $)^{4}$} & $(\$ 9,473.34)$ & & $\$ 1,363.76$ & \\
\hline \multicolumn{2}{|l|}{ NPV of investment for project ( 60 units $)^{5}$} & $(\$ 189,466.80)$ & & $\$ 27,275.20$ & \\
\hline \multicolumn{6}{|l|}{ Assumptions } \\
\hline \multicolumn{6}{|l|}{ Inflation rate: $2.5 \%$} \\
\hline \multicolumn{6}{|l|}{ Discount rate: $7.00 \%$} \\
\hline \multicolumn{6}{|l|}{ Loan interest rate: $5.00 \%$} \\
\hline \multicolumn{6}{|l|}{ Federal incentive rate: $26.00 \%$} \\
\hline \multicolumn{6}{|l|}{ Price of electricity in $2021: \$ 11.98 / \mathrm{kWh}$} \\
\hline \multicolumn{6}{|c|}{ Value of export = Retail price of electricity } \\
\hline \multicolumn{6}{|c|}{ Common areas are excluded } \\
\hline \multicolumn{6}{|l|}{ Notes: } \\
\hline \multicolumn{6}{|c|}{ (1) Total load multiplied by predicted price of energy } \\
\hline \multicolumn{6}{|c|}{ (2) Total export multiplied by predicted price of energy } \\
\hline \multicolumn{6}{|c|}{ (3) Total cost of financing and operating minus total value of exported energy } \\
\hline \multicolumn{6}{|l|}{ (4) (3)-(1) } \\
\hline (5) (4) multiplied by 20 & & & & & \\
\hline
\end{tabular}

The analysis suggests that with a long-term financing mechanism available, the net present cost of the zero-energy LIHTC apartments in Richmond, VA is lower than that of otherwise identical conventional apartments that have no renewable energy generation systems. Table 9 presents the results of the 30-year Monte Carlo cash-flow analysis of the six climatic divisions based on the same assumptions presented in Table 8 with randomized location-specific energy price, load, generation. Except for Norton, where the combination of low solar radiation, low ambient temperature, and low energy price reduces the value of investment, the NPV of investment in other cities is positive at zero or low risk of loss. Table A3 describes the two-way sensitivity of the 
simulated NPVs to installation cost and price of exported energy in Richmond, VA and Table 10 describes the sensitivity of the simulated NPVs to installation cost assuming equal prices for exported and delivered energy in all climatic divisions. The results suggest that achieving zeroenergy LIHTC apartments, even with a 15 percent incentive, is feasible with low risk margins in many locations across the state. The presented sensitivity analysis can help the reader estimate impacts of further incentives from the state, locality, or the LIHTC program or potential reductions in technology costs in the next few years. At the $1.87 \$ / \mathrm{Wdc}$ installation rate (25 percent incentive), additional scenarios are examined to show the impacts of decreasing or increasing future price of energy by 10 percent by the year 2050 corresponding to the US DOE forecasts. The magnitude of effects of discount rates ranging from 6-8 percent on financial outcomes presented in the current sensitivity analysis seem negligible.

Table 9 Monte Carlo financial analysis for all climatic divisions

\begin{tabular}{lllllll}
\hline & Norfolk & Richmond & Lynchburg & Fairfax & Staunton & Norton \\
\hline $\begin{array}{l}\text { Residential electricity rate 2020 (Cent/kWh) } \\
\text { Commercial electricity rate 2020 (Cent/kWh) }\end{array}$ & 11.81 & 11.81 & 10.71 & 11.81 & 11.81 & 10.13 \\
NPV of investment & & 7.80 & 8.56 & 7.80 & 7.80 & 8.63 \\
$\quad$ Mean & $\$ 130,672$ & $\$ 27,339$ & $\$ 6,259$ & $\$ 87,249$ & $\$ 94,365$ & $(\$ 55,057)$ \\
$\quad$ Standard deviation & $\$ 26,405$ & $\$ 23,644$ & $\$ 22,379$ & $\$ 25,408$ & $\$ 25,690$ & $\$ 20,651$ \\
$\quad$ Min & $\$ 37,986$ & $(\$ 55,612)$ & $(\$ 87,724)$ & $(\$ 26,934)$ & $\$ 6,739$ & $(\$ 130,664)$ \\
Max & $\$ 319,740$ & $\$ 469,866$ & $\$ 96,945$ & $\$ 370,786$ & $\$ 307,244$ & $\$ 101,252$ \\
$\quad$ Risk of loss & $0.00 \%$ & $12.01 \%$ & $38.68 \%$ & $0.04 \%$ & $0.00 \%$ & $99.58 \%$ \\
\hline
\end{tabular}

Table A4 presents the results of a statistical two-sample t-test with equal variances for Richmond, VA at 26 percent incentive, suggesting that the NPV obtained from subtracting the net present cost of the implementation of the rooftop residential PV systems from the discounted present cost of energy of the same apartments without PV systems is statistically significant. 
Table 10 Sensitivity of simulated NPVs to installation cost assuming equal prices for exported and delivered energy

\begin{tabular}{|c|c|c|c|c|c|c|c|}
\hline Cost $(\$ / W d c)$ & & Norfolk & Richmond & Lynchburg & Fairfax & Staunton & Norton \\
\hline $2.12(\$ / W d c)$ & Mean NPV & $\$ 62,725$ & $(\$ 40,799)$ & $(\$ 61,371)$ & $\$ 19,668$ & $\$ 26,412$ & $(\$ 122,984)$ \\
\hline \multirow[t]{2}{*}{ (2.49+15\% incentive) } & S.D. & $\$ 26,577$ & $\$ 23,209$ & $\$ 22,774$ & $\$ 25,113$ & $\$ 25,290$ & $\$ 20,444$ \\
\hline & Risk of loss & $1 \%$ & $96 \%$ & $100 \%$ & $21 \%$ & $15 \%$ & $100 \%$ \\
\hline $1.99(\$ / \mathrm{Wdc})$ & Mean NPV & $\$ 93,776$ & $(\$ 9,226)$ & $(\$ 30,740)$ & $\$ 50,386$ & $\$ 57,362$ & $(\$ 92,188)$ \\
\hline \multirow[t]{2}{*}{$(2.49+20 \%$ incentive) } & S.D. & $\$ 26,747$ & $\$ 23,508$ & $\$ 22,683$ & $\$ 25,343$ & $\$ 25,635$ & $\$ 20,707$ \\
\hline & Risk of loss & $0 \%$ & $66 \%$ & $91 \%$ & $2 \%$ & $1 \%$ & $100 \%$ \\
\hline $1.87(\$ / \mathrm{Wdc})$ & Mean NPV & $\$ 124,017$ & $\$ 21,188$ & $(\$ 247)$ & $\$ 81,452$ & $\$ 88,097$ & $(\$ 61,219)$ \\
\hline \multirow[t]{2}{*}{$(2.49+25 \%$ incentive $)$} & S.D. & $\$ 26,442$ & $\$ 23,066$ & $\$ 22,445$ & $\$ 25,675$ & $\$ 25,470$ & $\$ 20,379$ \\
\hline & Risk of loss & $0 \%$ & $18 \%$ & $51 \%$ & $0 \%$ & $0 \%$ & $100 \%$ \\
\hline $1.87(\$ / \mathrm{Wdc})$ & Mean NPV & $\$ 93,640$ & $(\$ 5,341)$ & $(\$ 25,607)$ & $\$ 52,572$ & $\$ 59,503$ & $(\$ 84,566)$ \\
\hline$(2.49+25 \%$ incentive) & S.D. & $\$ 25,720$ & $\$ 22,951$ & $\$ 21,845$ & $\$ 24,465$ & $\$ 24,538$ & $\$ 19,913$ \\
\hline$(-10 \%$ energy price by 2050$)$ & Risk of loss & $0 \%$ & $60 \%$ & $88 \%$ & $2 \%$ & $1 \%$ & $100 \%$ \\
\hline $1.87(\$ / \mathrm{Wdc})$ & Mean NPV & $\$ 155,201$ & $\$ 47,524$ & $\$ 25,934$ & $\$ 109,623$ & $\$ 116,877$ & $(\$ 37,723)$ \\
\hline (2.49+25\% incentive) & S.D. & $\$ 27,915$ & $\$ 24,127$ & $\$ 24,443$ & $\$ 25,972$ & $\$ 26,570$ & $\$ 21,289$ \\
\hline$(+10 \%$ energy price by 2050$)$ & Risk of loss & $0 \%$ & $2 \%$ & $13.68 \%$ & $0 \%$ & $0 \%$ & $96 \%$ \\
\hline $1.74(\$ / \mathrm{Wdc})$ & Mean NPV & $\$ 155,324$ & $\$ 51,938$ & $\$ 31,159$ & $\$ 112,048$ & $\$ 90,813$ & $(\$ 30,365)$ \\
\hline \multirow[t]{2}{*}{$(2.49+30 \%$ incentive $)$} & S.D. & $\$ 26,724$ & $\$ 23,208$ & $\$ 22,583$ & $\$ 25,522$ & $\$ 26,935$ & $\$ 20,694$ \\
\hline & Risk of loss & $0 \%$ & $1 \%$ & $8 \%$ & $0 \%$ & $0 \%$ & $93 \%$ \\
\hline \multirow{3}{*}{$\begin{array}{l}1.62(\$ / \mathrm{Wdc}) \\
(2.49+35 \% \text { incentive })\end{array}$} & Mean NPV & $\$ 186,291$ & $\$ 82,995$ & $\$ 61,682$ & $\$ 142,680$ & $\$ 149,734$ & $\$ 497$ \\
\hline & S.D. & $\$ 27,014$ & $\$ 23,165$ & $\$ 22,571$ & $\$ 25,264$ & $\$ 25,488$ & $\$ 20,485$ \\
\hline & Risk of loss & $0 \%$ & $0 \%$ & $0 \%$ & $0 \%$ & $0 \%$ & $50 \%$ \\
\hline \multirow{3}{*}{$\begin{array}{l}1.49(\$ / \mathrm{Wdc}) \\
(2.49+40 \% \text { incentive })\end{array}$} & Mean NPV & $\$ 216,827$ & $\$ 113,598$ & $\$ 92,457$ & $\$ 173,709$ & $\$ 180,426$ & $\$ 31,109$ \\
\hline & S.D. & $\$ 26,613$ & $\$ 23,438$ & $\$ 22,347$ & $\$ 25,239$ & $\$ 25,499$ & $\$ 20,566$ \\
\hline & Risk of loss & $0 \%$ & $0 \%$ & $0 \%$ & $0 \%$ & $0 \%$ & $6.31 \%$ \\
\hline \multirow{3}{*}{$\begin{array}{l}1.37(\$ / \mathrm{Wdc}) \\
(2.49+45 \% \text { incentive })\end{array}$} & Mean NPV & $\$ 247,893$ & $\$ 144,586$ & $\$ 123,280$ & $\$ 204,108$ & $\$ 211,022$ & $\$ 62,421$ \\
\hline & S.D. & $\$ 26,756$ & $\$ 23,318$ & $\$ 22,590$ & $\$ 25,804$ & $\$ 25,459$ & $\$ 21,032$ \\
\hline & Risk of loss & $0 \%$ & $0 \%$ & $0 \%$ & $0 \%$ & $0 \%$ & $0 \%$ \\
\hline
\end{tabular}

\section{Discussion}

\subsection{Key results and comparison with previous research}

Based on the 30-year discounted cash-flow analysis, the net present cost of the implementation of rooftop residential solar systems to achieve zero-energy LIHTC apartments in Virginia can be lower than the discounted present cost of energy of otherwise identical apartments that have no renewable energy generation systems, and the value of cost savings can be statistically significant. The investment value often depends on the zero-energy building definition, weather characteristics, 
retail price of electricity, and incentive rate. The DOE's definition of zero-energy building implies that these buildings should progress the restoration of the 32.31 percent loss (based on data from the 2010s) to the infrastructure system. A potential problem with this requirement in Virginia, where the solar potential is lower than that of states located in the South East, South West, and West regions, is not financial viability but the need for extra installation space. The analysis presented here relaxes this specification to minimize the required module area. According to the SAM analysis, each PV module should increase by $50 \%$ in size to fully restore the source energy loss, which equals to an increase from $1,680 \mathrm{sm}(\sim 18,083 \mathrm{sf})$ to $2,520 \mathrm{sm}(\sim 27,125.1 \mathrm{sf})$ in total solar array installation area, whereas the total usable rooftop area of the building is approximately $2500 \mathrm{sm}(\sim 26,900 \mathrm{sf})$ in the best-case scenario. Offsetting the total load of common areas, if included in the analysis, would require an additional $350 \mathrm{sm}(\sim 3,767 \mathrm{sf})$ rooftop space. In areas where the combination of high solar potential and price of energy exists, an increase in the array size can increase the investment's net present value. Therefore, it is feasible to fully offset the annual load of the entire building, but achieving the DOE definition of zero-energy building requires project designers to consider the spatial needs of solar PV systems at the conceptual design stage.

Although zero-energy LIHTC buildings can be more cost-effective than otherwise identical LIHTC buildings in the long run, the costs associated with PV systems are not evenly distributed in the state, leaving some areas like the Southeast more receptive to adoption of distributed generation systems than others like the Southwest. Differences in solar radiation, ambient temperature, energy prices, and diminishing prospects of the federal solar tax credit can affect consumers' willingness to invest in PV systems. Analyzing these variations and the significance of carbon emissions avoided as a result of renewable energy generation is a key to support the 
construction industry in bridging the gap to zero-energy buildings, particularly in low-income housing.

Achieving annual balance of primary energy is a required step toward performance improvement, but zero-energy LIHTC design and upgrade considerations can include an optimized combination of power storage systems, mechanical and electrical operation control systems, and additional energy-efficiency measures that help buildings achieve balance in all individual months, reduce stress on existing power infrastructure, reduce greenhouse gas emissions, and increase the building's economic value [64,65]. The analysis of HERS score presented here suggests that further reductions in the embodied energy are achievable by applying construction methods, systems, and components that are more energy-efficient than conventional ones. Virginia's solar potential is not as abundant as that of other US states located at lower latitudes, and achieving a cost-effective balance that compensates for losses in primary to final energy conversion may not be widely implemented soon using distributed generation but the potential to reduce energy demand by improving design and construction standards exists.

\subsection{Zero-energy LIHTC opportunities and barriers}

Until recently, variability in net-metering agreements across utilities created barriers to the adoption of zero-energy LIHTC development. For example, a developer would have to analyze energy consumption rates $(\$ / \mathrm{kWh})$ and a different rate for producing and selling excess $\mathrm{kWh}$ to the local utilities. Utilities would charge $\$ 0.11 / \mathrm{kWh}$ for consumption, and only pay $\$ 0.05 / \mathrm{kWh}$ for excess generation. The difference between consumption and generation rates disincentivizes solar PV in housing and general market confusion. Following a 2015 change to Virginia law (Virginia Code §56-594) investor-owned utilities like Dominion and Appalachian Power and cooperatives compensate customers at one-to-one retail rate with a system size limit of 1,000 kW. In addition, 
Many state codes (including Virginia Code $§ 58.1-3661$ ) now allow localities to offer property tax exemption on solar energy equipment for a certain number of years. State, municipalities, utility companies, or other organizations willing to promote solar energy have offered limited-time rebates that can help significantly reduce installation costs. Other than direct federal, state, and local incentives, potential mechanisms to increase low-income citizens' access to renewable energy include loan loss reserve, on-bill financing or recovery, and revised underwriting criteria [66].

In 2019, the General Assembly of Virginia approved the Low-to-Moderate Income Solar Loan and Rebate Fund to provide a solar financing platform for solar installations or energy efficiency improvements specific to residents with household income at or below 80 percent of the state or regional median income. Other recent legislative developments in the state include House bill HB 572 Distributed renewable energy sales of electricity under third-party agreements and Senate bill SB 629 Shared solar programs, which promote the establishment of distributed renewable energy and allow customers to purchase electric power through a subscription in a shared solar facility. The Low-Income Energy Affordability Data (LEAD) Tool (www.energy.gov/eere/slsc/maps/leadtool) and the Database of State Incentives for Renewables \& Efficiency (DSIRE) (www.dsireusa.org) provide data and information on low- and moderate-income renewable energy policy in the US [67].

Despite significant decreases in total installation costs and increases in emerging opportunities for residential systems, barriers to zero-energy LIHTC deployment persist. Existing multifamily buildings have limited operating reserves, lack proper orientation or rooftop space to maximize energy generation, and are in need of roof repair and replacement, thus, making it difficult for owners and operators to allocate sufficient funding for direct financing and installation of solar 
systems outside the already established 15-year operation and maintenance cash-flow schedules. Energy storage systems could increase the potential value of residential systems at the building level (e.g., through allowing for back-up power in the event of a grid outage and reducing residential demand charges through load shifting) and at the grid level (e.g., allowing for voltage and frequency regulation, deferred infrastructure investment, and resource adequacy) [52]. Nonetheless, PV-plus-storage systems are still expensive to purchase, the permitting process for installing and operating storage devices are complicated, and the interconnection and net metering is complex and costly. Finally, the lack of longitudinal performance data and regulatory nature of state QAPs creates uncertainty for developers and limits their willingness to test innovative technologies and approaches toward zero-energy LIHTC developments.

\subsection{Recommendations}

Beyond variability in consumption and generation rates, metering infrastructure, (e.g., sub or master-metered), impacts the value of investment in zero-energy LIHTC developments. In submetered developments each apartment's utility usage is measured individually and tenants pay through accounts they themselves establish with utility companies (Figure 9a). In master-metered developments (Figure 9b) the owner pays for all the utility costs and passes the costs on to individual tenants within their rent costs [65]. Within each LIHTC application, the developer identifies if the utilities will be master or sub-metered. There is little incentive to invest in energyefficiency and renewable energy systems in master-metered developments since the developers cannot distribute additional costs on tenant rents due to the competitive nature of many rental assistance or housing production programs. 


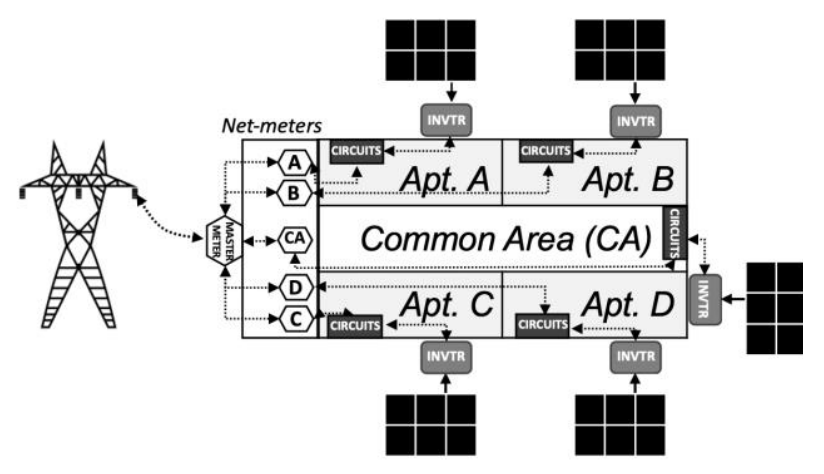

a)

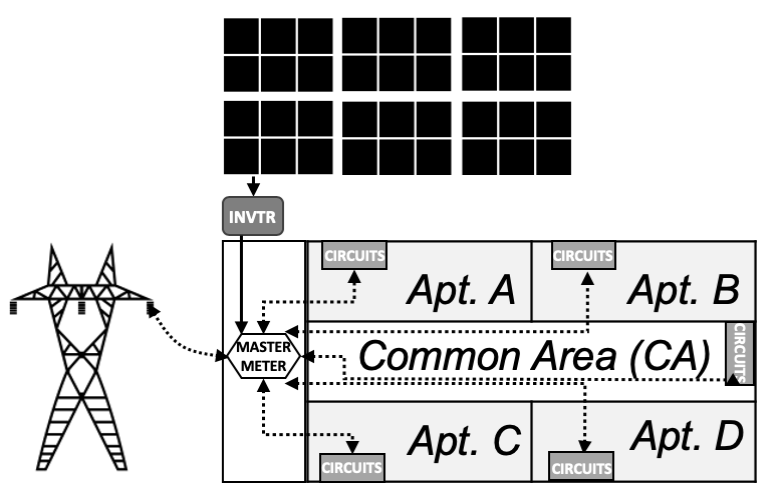

b)

Figure 9 Common zero-energy LIHTC metering approaches a) sub-metered approach b) master metered approach

Submetering may to some extent address the so-called "split-incentive" problem in energyefficiency transactions, at least by allowing individual residents to control the use of energy. In many cases, developers are allowed to sub-meter common areas at commercial rates, which helps reduce costs of operation and maintenance but decreases the value of investment in renewable energy systems for common areas. Therefore, variations in metering infrastructure and rates and the resulting effects should be considered in the financial analysis of individual zero-energy LIHTC buildings. In practice, housing programs have started to increase incentives where developers can demonstrate that tenants can benefit from energy-efficiency or renewable energy generation systems [65].

It is recommended that state housing finance agencies evaluate new methods for metering developments. For example, in addition to a single utility provided master meter, zero-energy LIHTC developments can employ Circuit-level Owner Metering (Figure 10) to better manage development performance. The approach provides real-time, high-resolution data on unit-level and circuit-level energy consumption, as well as solar system performance. Extant research suggests occupants are generally poor at managing systems with lags in information and delayed evaluation loops [68]. Current utility-provided metering technologies fail to provide customers with data that 
is usable or timely in managing system performance, improving occupant experiences, or meeting zero-energy goals. With this approach, developers install metering hardware in each apartment's circuit panel and measure energy use in 1-second intervals. The accompanying software allows easy analysis of performance at circuit, unit, and development levels and could be leveraged for predictive analytics (e.g., identifying HVAC system maintenance issues before they occur). Circuit-level meters are commercially available starting at $\sim \$ 300$ per system and have been employed in pilot zero-energy developments [69].

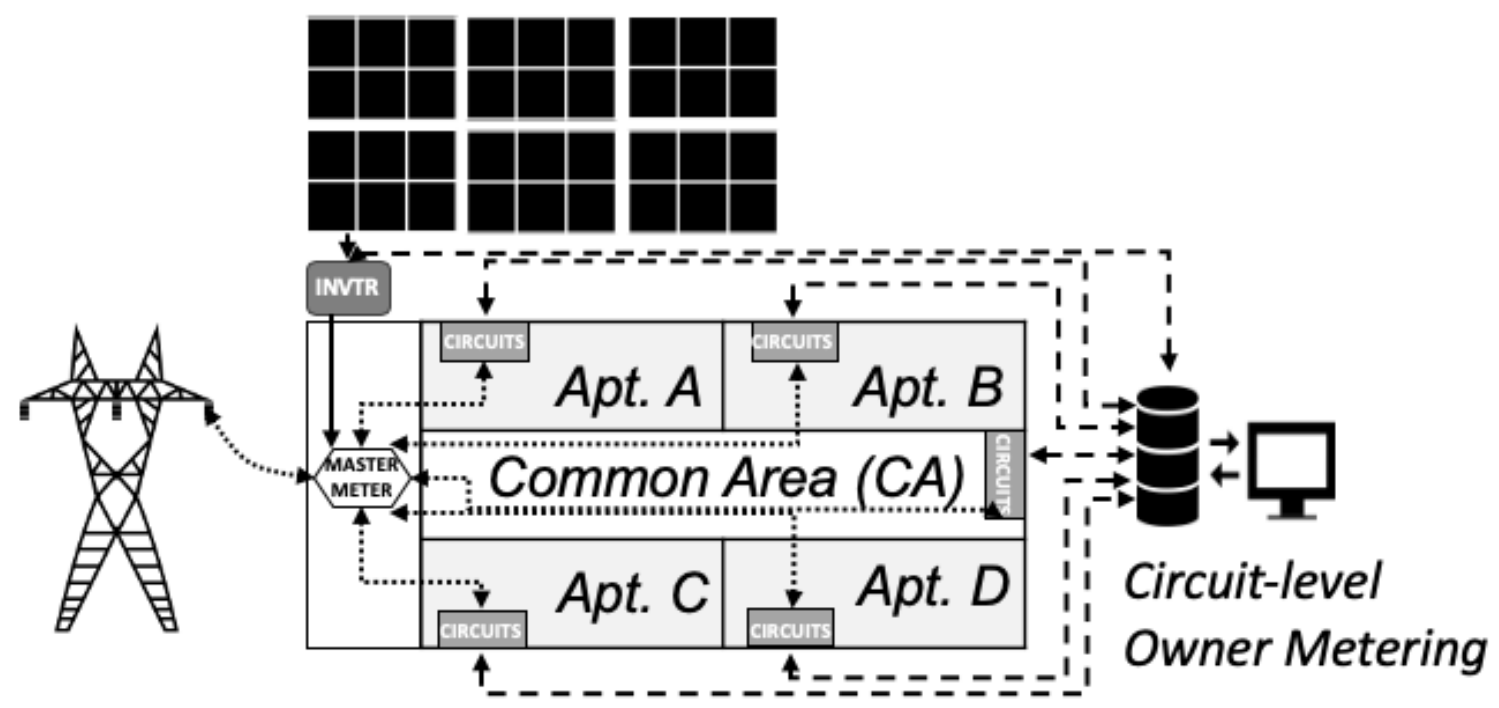

Figure 10 Circuit-level Owner Metering

The authors also recommend analyzing the net present values of incentivizing distributed generation using PV systems for specific stakeholders, such as private sector interests, the economy, and the government budget. Incentivizing PV systems should include an analysis of state-wide variations in solar radiation as QAP selection criteria and allocate additional scores for developments located in climatic divisions with less-than-average solar potential. Since the existing federal solar tax credit is expected to gradually decrease in the coming years, it is essential 
for housing agencies to identify financing mechanisms that help fill the gap to maintain the feasibility of zero-energy LIHTC developments in the 2020s.

As evidenced by past research and the energy use data analysis presented here, a significant part of variability in energy consumption is attributable to human-building interaction. Since the extra spending on utilities impacts housing affordability and economic well-being of low-income residents, empowering final users to have an active role in reducing energy consumption, particularly for heating and cooling purposes, is becoming increasingly important [70]. Such activities can be included in the state's free energy efficiency and appliance testing and repair services that help create energy savings by reducing energy bills for qualified low-income, elderly, and disabled residents in rental and owner-occupied houses [71]. To further reduce energy demand, architects and engineers can design zero-energy LIHTC projects to maximize energy-efficiency and include monitoring and control technologies that reduce user-imposed inefficiencies and contribute to cost-effective operation of new or existing buildings $[72,73]$.

\section{Conclusion}

This study investigated the feasibility of state-wide zero-energy affordable housing by analyzing historical data on climate, energy use, and energy system costs in the Commonwealth of Virginia, US. Addressing the knowledge gap in the literature on solar panel adoption in low-income housing, the study contributes to the body of knowledge through the examination of generalizable statistical energy load prediction methods and simulation-based risk analysis, which have essential applications in planning and policy analysis but are less explored in existing feasibility studies. The study suggests that, in most areas in Virginia, the net present life-cycle cost of the implementation of rooftop residential solar systems to achieve zero-energy LIHTC buildings is currently lower than the discounted present cost of energy of otherwise identical conventional 
buildings that have no renewable energy generation systems, and the value of cost savings is statistically significant. The annual electricity generated using the PV system in the 60-unit zeroenergy LIHTC study case is $\sim 146,060 \mathrm{kWh} / \mathrm{yr}$. The greenhouse gas emissions avoided by the PV system per year is equivalent to $\sim 103$ metric tons of carbon dioxide. This avoided carbon dioxide in 30 years amounts to nearly 348,600 gallons burnt of gasoline or 7,687,620 miles driven by an average passenger vehicle, suggesting the presence of great potentials for emission reductions, thus, contributing to economic, environmental, and equity effects in Virginia through promoting zero-energy LIHTC developments in the 2020s [74]. Based on the presented analysis, conventional LIHTC apartments built in the 2010s, which are more energy-efficient than those included in the study sample, can be converted to zero-energy with potentially higher than currently estimated investment rates of return. Since buildings represent nearly 40 percent of global energy use and 30 percent of global greenhouse gas emissions, investments in distributed renewable energy generation in buildings can significantly enhance environmental sustainability and climate change mitigation and, concurrently, address housing affordability and economic development. 


\section{Appendix}

Table A1 Simple regression model of electricity price $\left(\mathrm{Obs}=29\right.$, Adjusted $\mathrm{R}^{2}=0.8472$, Root MSE $\left.=0.63732\right)$

\begin{tabular}{lllllll}
\hline & Coef. & Std. Err. & $\mathrm{t}$ & $\mathrm{P}>\mathrm{t}$ & [95\% C.I.] & [95\% C.I.] \\
\hline Year & 0.1768079 & .0141452 & 12.50 & 0.000 & 0.1477843 & 0.2058315 \\
_cons & -345.3468 & 28.34729 & -12.18 & 0.000 & -403.5106 & -287.1829 \\
\hline
\end{tabular}

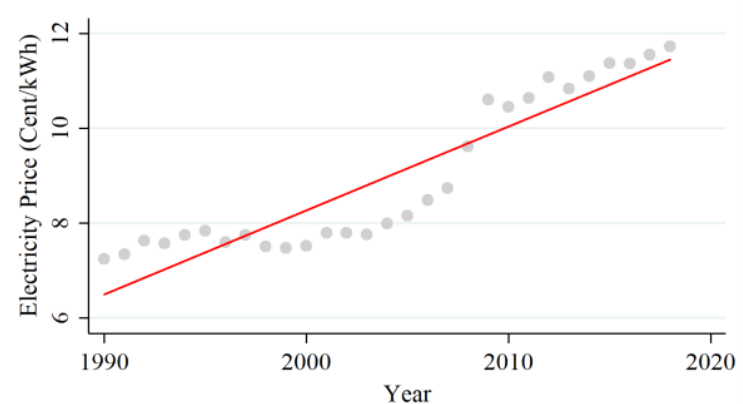

- Average price of electricity (Cent/kWh) — Fitted values

Figure A1 Average retail price of electricity for residential use in Virginia

Table A2 Predicted mean loads (kWh/Month)

\begin{tabular}{llllllll}
\hline Time & Richmond, VA & S.E. & Norfolk (D1) & Lynchburg (D3) & Fairfax (D4) & Staunton (D5) & Norton (D6) \\
\hline January & 784.37 & 15.74 & 716.24 & 822.99 & 901.54 & 931.70 & 894.59 \\
February & 741.40 & 15.75 & 692.20 & 778.87 & 855.24 & 885.69 & 832.99 \\
March & 612.04 & 15.77 & 577.28 & 637.27 & 733.31 & 755.20 & 692.89 \\
April & 428.81 & 15.78 & 416.24 & 456.37 & 559.72 & 584.85 & 519.60 \\
May & 393.46 & 14.28 & 408.97 & 368.13 & 422.93 & 392.95 & 362.44 \\
June & 428.98 & 14.58 & 461.29 & 367.54 & 327.77 & 252.84 & 267.40 \\
July & 472.89 & 14.60 & 515.78 & 413.15 & 394.52 & 299.29 & 293.97 \\
August & 449.54 & 14.61 & 511.54 & 383.82 & 363.94 & 270.93 & 288.46 \\
September & 401.45 & 14.63 & 463.90 & 343.02 & 345.25 & 295.29 & 265.85 \\
October & 403.62 & 14.62 & 366.13 & 441.58 & 504.06 & 564.24 & 503.14 \\
November & 510.55 & 14.60 & 449.84 & 559.66 & 596.18 & 652.10 & 626.66 \\
December & 649.87 & 14.60 & 580.72 & 695.04 & 757.63 & 795.24 & 743.75 \\
Year (2013) & 6276.97 & & 6160.14 & 6267.45 & 6762.10 & 6680.31 & 6291.73 \\
\hline
\end{tabular}


Table A3 Sensitivity of simulated project NPV to installation cost and price of exported energy in Richmond, VA

\begin{tabular}{|c|c|c|c|c|c|c|c|}
\hline \multirow[t]{2}{*}{ Cost $(\$ / \mathrm{Wdc})$} & & \multicolumn{6}{|c|}{ Exported to Delivered Electricity Price Ratio } \\
\hline & & $0 \%$ & $20 \%$ & $40 \%$ & $60 \%$ & $80 \%$ & $100 \%$ \\
\hline 2.12 & Mean NPV & $(\$ 132,499)$ & $(\$ 114,213)$ & $(\$ 96,261)$ & $(\$ 77,642)$ & $(\$ 58,448)$ & $(\$ 40,799)$ \\
\hline \multirow[t]{2}{*}{ ( $2.49+15 \%$ incentive) } & S.D. & $\$ 191,374$ & $\$ 152,437$ & $\$ 116,473$ & $\$ 78,414$ & $\$ 43,808$ & $\$ 23,209$ \\
\hline & Risk of loss & $75 \%$ & $77 \%$ & $79 \%$ & $84 \%$ & $91 \%$ & $96 \%$ \\
\hline \multirow{3}{*}{$\begin{array}{l}1.99 \\
(2.49+20 \% \text { incentive })\end{array}$} & Mean NPV & $(\$ 103,656)$ & $(\$ 82,006)$ & $(\$ 66,450)$ & $(\$ 47,615)$ & $(\$ 28,267)$ & $(\$ 9,226)$ \\
\hline & S.D. & $\$ 191,102$ & $\$ 154,361$ & $\$ 115,272$ & $\$ 78,914$ & $\$ 44,466$ & $\$ 23,508$ \\
\hline & Risk of loss & $71 \%$ & $71 \%$ & $72 \%$ & $73 \%$ & $74 \%$ & $66 \%$ \\
\hline \multirow{3}{*}{$\begin{array}{l}1.87 \\
(2.49+25 \% \text { incentive })\end{array}$} & Mean NPV & $(\$ 71,024)$ & $\$(53,955)$ & $(\$ 35,649)$ & $(\$ 15,155)$ & $\$ 2,279$ & $\$ 21,188$ \\
\hline & S.D. & $\$ 190,222$ & $\$ 154,821$ & $\$ 114,549$ & $\$ 78,962$ & $\$ 43,783$ & $\$ 23,066$ \\
\hline & Risk of loss & $65 \%$ & $64 \%$ & $62 \%$ & $59 \%$ & $49 \%$ & $18 \%$ \\
\hline \multirow{3}{*}{$\begin{array}{l}1.74 \\
(2.49+30 \% \text { incentive })\end{array}$} & Mean NPV & $(\$ 41,370)$ & $(\$ 21,838)$ & $(\$ 4,083)$ & $\$ 15,337$ & $\$ 33,124$ & $\$ 51,938$ \\
\hline & S.D. & $\$ 190,301$ & $\$ 152,956$ & $\$ 115,881$ & $\$ 78,665$ & $\$ 43,984$ & $\$ 23,208$ \\
\hline & Risk of loss & $59 \%$ & $56 \%$ & $51 \%$ & $42 \%$ & $23 \%$ & $1 \%$ \\
\hline \multirow{3}{*}{$\begin{array}{l}1.62 \\
(2.49+35 \% \text { incentive })\end{array}$} & Mean NPV & $(\$ 10,178)$ & $\$ 9,108$ & $\$ 25,688$ & $\$ 45,307$ & $\$ 64,358$ & $\$ 82,995$ \\
\hline & S.D. & $\$ 189,545$ & $\$ 153,202$ & $\$ 115,841$ & $\$ 78,288$ & $\$ 43,912$ & $\$ 23,165$ \\
\hline & Risk of loss & $53 \%$ & $48 \%$ & $42 \%$ & $28 \%$ & $7 \%$ & $0 \%$ \\
\hline \multirow{3}{*}{$\begin{array}{l}1.49 \\
(2.49+40 \% \text { incentive })\end{array}$} & Mean NPV & $\$ 20,340$ & $\$ 38,983$ & $\$ 57,007$ & $\$ 76,358$ & $\$ 95,240$ & $\$ 113,598$ \\
\hline & S.D. & $\$ 191,897$ & $\$ 152,561$ & $\$ 115,212$ & $\$ 77,602$ & $\$ 43,804$ & $\$ 23,438$ \\
\hline & Risk of loss & $46 \%$ & $39 \%$ & $32 \%$ & $17 \%$ & $1 \%$ & $0 \%$ \\
\hline \multirow{3}{*}{$\begin{array}{l}1.25 \\
(2.49+45 \% \text { incentive })\end{array}$} & Mean NPV & $\$ 51,865$ & $\$ 70,815$ & $\$ 88,607$ & $\$ 106,372$ & $\$ 125,677$ & $\$ 144,586$ \\
\hline & S.D. & $\$ 189,706$ & $\$ 152,961$ & $\$ 113,422$ & $\$ 78,565$ & $\$ 44,123$ & $\$ 23,318$ \\
\hline & Risk of loss & $39 \%$ & $32 \%$ & $22 \%$ & $9 \%$ & $0 \%$ & $0 \%$ \\
\hline
\end{tabular}

Table A4 Two-sample $\mathrm{t}$ test with equal variances for Richmond, VA at 26 percent incentive

\begin{tabular}{|c|c|c|c|c|c|c|}
\hline Group & Obs & Mean & Std. Err. & Std. Dev. & [95\% Conf. & Interval] \\
\hline Conventional & 15,000 & 30726.21 & 77.67104 & 9512.721 & 30573.97 & 30878.46 \\
\hline Zero Energy & 15,000 & 29382.93 & 77.59321 & 9503.188 & 29230.83 & 29535.02 \\
\hline diff & & 1343.286 & 109.7884 & & 1128.096 & 1558.476 \\
\hline Ho: diff $=0$ & & & & & $\mathrm{t}=$ & 12.2352 \\
\hline Ha: diff $!=0$ & \multicolumn{4}{|c|}{$\operatorname{Pr}(|\mathrm{T}|>|\mathrm{t}|)=0.0000$} & $\mathrm{df}=$ & 29998 \\
\hline
\end{tabular}




\section{References}

1. USDOE How the United States uses energy Available online:

https://www.eia.gov/energyexplained/use-of-energy/ (accessed on Jun 9, 2020).

2. JCHS The State of the Nation's Housing 2019; Joint Center for Housing Studies of Harvard University., 2019;

3. HUD Low-Income Housing Tax Credits Available online: https://www.huduser.gov/portal/datasets/lihtc.html (accessed on Jun 9, 2020).

4. HUD LIHTC Database Access Available online: https://lihtc.huduser.gov/ (accessed on Jun 9, 2020).

5. Novogradac About the LIHTC Available online: https://www.novoco.com/resourcecenters/affordable-housing-tax-credits/lihtc-basics/about-lihtc (accessed on Apr 13, 2020).

6. McClure, K. What should be the future of the Low-Income Housing Tax Credit program? Hous. Policy Debate 2019, 29, 65-81.

7. Yeganeh, A.J.; McCoy, A.P.; Reichard, G.; Schenk, T.; Hankey, S. Green Building and Policy Innovation in Low-Income Housing Developments (LIHTC). 2020.

8. Ellen, I.G.; Horn, K.; Kuai, Y.; Pazuniak, R.; Williams, M.D. Effect of QAP Incentives on the Location of LIHTC Properties; Economic Systems Inc.: Falls Church, VA, 2015;

9. Zhao, D.; McCoy, A.P.; Agee, P.; Mo, Y.; Reichard, G.; Paige, F. Time effects of green buildings on energy use for low-income households: A longitudinal study in the United States. Sustain. Cities Soc. 2018, 40, 559-568, doi:10.1016/j.scs.2018.05.011.

10. Rai, V.; Reeves, D.C.; Margolis, R. Overcoming barriers and uncertainties in the adoption of residential solar PV. Renew. Energy 2016, 89, 498-505, doi:10.1016/j.renene.2015.11.080.

11. Kivimaa, P.; Mickwitz, P. The challenge of greening technologies-Environmental policy integration in Finnish technology policies. Res. Policy 2006, 35, 729-744.

12. Runhaar, H.; Driessen, P.; Uittenbroek, C. Towards a systematic framework for the analysis of environmental policy integration. Environ. Policy Gov. 2014, 24, 233-246.

13. Mohr, L.B. Determinants of Innovation in Organizations*. Am. Polit. Sci. Rev. 1969, 63, 111-126, doi:10.1017/S0003055400261510.

14. Singh, A.; Syal, M.; Grady, S.C.; Korkmaz, S. Effects of green buildings on employee health and productivity. Am. J. Public Health 2010, 100, 1665-1668.

15. Breysse, J.; Jacobs, D.E.; Weber, W.; Dixon, S.; Kawecki, C.; Aceti, S.; Lopez, J. Health outcomes and green renovation of affordable housing. Public Health Rep. 2011, 126, 64-75.

16. Bradshaw, W.; Connelly, E.F.; Cook, M.F.; Goldstein, J.; Pauly, J. The costs and benefits of green affordable housing. Camb. MA New Ecol. 2005.

17. Mueller, E.J.; Tighe, J.R. Making the case for affordable housing: Connecting housing with health and education outcomes. J. Plan. Lit. 2007, 21, 371-385.

18. VCHR The Impact of Energy Efficient Design and Construction on LIHTC Housing in Virginia; Housing Virginia, 2015;

19. Lapsa, M.V.; Brown, M.A.; Soni, A.; Southworth, K. Low-Income Energy Affordability: Conclusions From A Literature Review; Oak Ridge National Lab.(ORNL), Oak Ridge, TN (United States), 2020;

20. Schwartz, H.L.; Curtright, A.E.; Ogletree, C.; Thornton, E.; Jonsson, L. Energy Efficiency as a Tool for Preservation of Affordable Rental Housing; RAND Corporation: Santa Monica, California., 2018;

21. Deng, Y.; Wu, J. Economic returns to residential green building investment: The developers' perspective. Reg. Sci. Urban Econ. 2014, 47, 35-44.

22. Matisoff, D.C.; Noonan, D.S.; Flowers, M.E. Policy monitor-Green buildings: Economics and policies. Rev. Environ. Econ. Policy 2016, 10, 329-346.

23. Yeganeh, A.J.; McCoy, A.P.; Hankey, S. Green affordable housing: Cost-benefit analysis for zoning incentives. Sustainability 2019, 11, 1-24.

24. Walls, M.; Gerarden, T.; Palmer, K.; Bak, X.F. Is energy efficiency capitalized into home prices? Evidence from three US cities. J. Environ. Econ. Manag. 2017, 82, 104-124. 
25. Kahn, M.E.; Kok, N. The capitalization of green labels in the California housing market. Reg. Sci. Urban Econ. 2014, 47, 25-34.

26. Hughes, J.E.; Podolefsky, M. Getting green with solar subsidies: evidence from the California solar initiative. J. Assoc. Environ. Resour. Econ. 2015, 2, 235-275.

27. Deng, S.; Wang, R.Z.; Dai, Y.J. How to evaluate performance of net zero energy building - A literature research. Energy 2014, 71, 1-16, doi:10.1016/j.energy.2014.05.007.

28. Carrilho da Graça, G.; Augusto, A.; Lerer, M.M. Solar powered net zero energy houses for southern Europe: Feasibility study. Sol. Energy 2012, 86, 634-646, doi:10.1016/j.solener.2011.11.008.

29. EU Directive 2010/31/EU of the European Parliament and of the Council of 19 May 2010 on the energy performance of buildings; 2020;

30. CAPUC California long term energy efficiency strategic plan; California, 2008;

31. Berggren, B.; Hall, M.; Wall, M. LCE analysis of buildings - Taking the step towards Net Zero Energy Buildings. Energy Build. 2013, 62, 381-391, doi:10.1016/j.enbuild.2013.02.063.

32. DOE Guidelines for Participating in the DOE Zero Energy Ready Home Program Available online: https://www.energy.gov/eere/buildings/guidelines-participating-doe-zero-energy-ready-homeprogram (accessed on Jul 2, 2020).

33. DOE Federal new buildings handbook for net zero energy, water, and waste 2017.

34. D'Agostino, D.; Mazzarella, L. What is a Nearly zero energy building? Overview, implementation and comparison of definitions. J. Build. Eng. 2019, 21, 200-212, doi:10.1016/j.jobe.2018.10.019.

35. Salom, J.; Widén, J.; Candanedo, J.; Sartori, I.; Voss, K.; Marszal, A. Understanding net zero energy buildings: evaluation of load matching and grid interaction indicators. In Proceedings of the proceedings of building simulation; 2011; Vol. 6, pp. 2514-2521.

36. Sartori, I.; Napolitano, A.; Voss, K. Net zero energy buildings: A consistent definition framework. Energy Build. 2012, 48, 220-232, doi:10.1016/j.enbuild.2012.01.032.

37. Guarino, F.; Cassarà, P.; Longo, S.; Cellura, M.; Ferro, E. Load match optimisation of a residential building case study: A cross-entropy based electricity storage sizing algorithm. Appl. Energy 2015, 154, 380-391, doi:10.1016/j.apenergy.2015.04.116.

38. Cellura, M.; Guarino, F.; Longo, S.; Mistretta, M. Different energy balances for the redesign of nearly net zero energy buildings: An Italian case study. Renew. Sustain. Energy Rev. 2015, 45, 100 112, doi:10.1016/j.rser.2015.01.048.

39. Mohamed, A.; Hasan, A.; Sirén, K. Fulfillment of net-zero energy building (NZEB) with four metrics in a single family house with different heating alternatives. Appl. Energy 2014, 114, 385-399, doi:10.1016/j.apenergy.2013.09.065.

40. AlAjmi, A.; Abou-Ziyan, H.; Ghoneim, A. Achieving annual and monthly net-zero energy of existing building in hot climate. Appl. Energy 2016, 165, 511-521, doi:10.1016/j.apenergy.2015.11.073.

41. Aagreh, Y.; Al-Ghzawi, A. Feasibility of utilizing renewable energy systems for a small hotel in Ajloun city, Jordan. Appl. Energy 2013, 103, 25-31, doi:10.1016/j.apenergy.2012.10.008.

42. Li, D.H.W.; Yang, L.; Lam, J.C. Zero energy buildings and sustainable development implications - A review. Energy 2013, 54, 1-10, doi:10.1016/j.energy.2013.01.070.

43. Amasyali, K.; El-Gohary, N.M. A review of data-driven building energy consumption prediction studies. Renew. Sustain. Energy Rev. 2018, 81, 1192-1205, doi:10.1016/j.rser.2017.04.095.

44. Salci, S.; Jenkins, G.P. Incorporating risk and uncertainty in cost-benefit analysis. Dev. Discuss. Pap. 2016, 9.

45. Sartori, D.; Catalano, G.; Genco, M.; Pancotti, C.; Sirtori, E.; Vignetti, S.; Bo, C. Guide to costbenefit analysis of investment projects. Economic appraisal tool for cohesion policy 2014-2020. 2014.

46. Eeckhoudt, L.; Gollier, C.; Schlesinger, H. Economic and financial decisions under risk; Princeton University Press, 2011;

47. Boardman, A.E.; Greenberg, D.H.; Vining, A.R.; Weimer, D.L. Cost-benefit analysis: concepts and practice; Cambridge University Press, 2017;

48. De Rus, G. Introduction to cost-benefit analysis: looking for reasonable shortcuts; Edward Elgar 
Publishing, 2010;

49. Management, O. of; Budget Guidelines and discount rates for benefit-cost analysis of federal programs. OMB Circ. No -94 Revis. 1992.

50. Burgess, D.F.; Zerbe, R.O. Appropriate discounting for benefit-cost analysis. J. Benefit-Cost Anal. 2011, 2, 1-20.

51. Ferrante, A.; Cascella, M.T. Zero energy balance and zero on-site $\mathrm{CO} 2$ emission housing development in the Mediterranean climate. Energy Build. 2011, 43, 2002-2010, doi:10.1016/j.enbuild.2011.04.008.

52. Ardani, K.; O’Shaughnessy, E.; Fu, R.; McClurg, C.; Huneycutt, J.; Margolis, R. Installed cost benchmarks and deployment barriers for residential solar photovoltaics with energy storage: Q1 2016; National Renewable Energy Lab.(NREL), Golden, CO (United States), 2016;

53. SEIA Solar Market Insight Report 2020 Q2 Available online: https://www.seia.org/researchresources/solar-market-insight-report-2020-q2 (accessed on Jul 13, 2020).

54. NREL U.S. Solar Photovoltaic System Cost Benchmark: Q1 2018; National Renewable Energy Laboratory., 2018;

55. Weron, R. Electricity price forecasting: A review of the state-of-the-art with a look into the future. Int. J. Forecast. 2014, 30, 1030-1081, doi:10.1016/j.ijforecast.2014.08.008.

56. Blair, N.J.; DiOrio, N.A.; Freeman, J.M.; Gilman, P.; Janzou, S.; Neises, T.W.; Wagner, M.J. System Advisor Model (SAM) General Description (Version 2017.9. 5); National Renewable Energy Lab.(NREL), Golden, CO (United States), 2018;

57. Gilman, P.; Dobos, A.; DiOrio, N.A.; Freeman, J.M.; Janzou, S.; Ryberg, D. SAM Photovoltaic Model Technical Reference Update; National Renewable Energy Lab.(NREL), Golden, CO (United States), 2018;

58. FRED Consumer Price Index for All Urban Consumers: Electricity in U.S. City Average Available online: https://fred.stlouisfed.org/series/CUSR0000SEHF01 (accessed on Jun 29, 2020).

59. EIA Annual Energy Outlook 2020; U.S. Energy Information Administration, Office of Energy Analysis, U.S. Department of Energy, Washington, DC 20585, 2020;

60. Zhao, D.; McCoy, A.P.; Du, J.; Agee, P.; Lu, Y. Interaction effects of building technology and resident behavior on energy consumption in residential buildings. Energy Build. 2017, 134, 223-233, doi:10.1016/j.enbuild.2016.10.049.

61. Huebner, G.M.; Hamilton, I.; Chalabi, Z.; Shipworth, D.; Oreszczyn, T. Explaining domestic energy consumption - The comparative contribution of building factors, socio-demographics, behaviours and attitudes. Appl. Energy 2015, 159, 589-600, doi:10.1016/j.apenergy.2015.09.028.

62. Delzendeh, E.; Wu, S.; Lee, A.; Zhou, Y. The impact of occupants' behaviours on building energy analysis: A research review. Renew. Sustain. Energy Rev. 2017, 80, 1061-1071, doi:10.1016/j.rser.2017.05.264.

63. Martinaitis, V.; Zavadskas, E.K.; Motuzienè, V.; Vilutienė, T. Importance of occupancy information when simulating energy demand of energy efficient house: A case study. Energy Build. 2015, 101, 64-75, doi:10.1016/j.enbuild.2015.04.031.

64. Penna, P.; Prada, A.; Cappelletti, F.; Gasparella, A. Multi-objectives optimization of Energy Efficiency Measures in existing buildings. Energy Build. 2015, 95, 57-69, doi:10.1016/j.enbuild.2014.11.003.

65. Popescu, D.; Bienert, S.; Schützenhofer, C.; Boazu, R. Impact of energy efficiency measures on the economic value of buildings. Appl. Energy 2012, 89, 454-463, doi:10.1016/j.apenergy.2011.08.015.

66. NREL Low- and Moderate-Income Solar Policy Basics Available online: https://www.nrel.gov/statelocal-tribal/lmi-solar.html (accessed on Jul 2, 2020).

67. Ma, O.; Laymon, K.; Day, M.H.; Bracho, R.; Weers, J.D. (ORCID:000000029135655X); Vimont, A.J. Low-Income Energy Affordability Data (LEAD) Tool Methodology; National Renewable Energy Lab. (NREL), Golden, CO (United States), 2019;

68. Sterman, J.D. Misperceptions of feedback in dynamic decision making. Organ. Behav. Hum. Decis. Process. 1989, 43, 301-335. 
69. Agee, P.; Reichard, G.; McCoy, A.; Kleiner, B.; Hamm, T. Closing the Post-Occupancy Performance Gap in Zero Energy Housing. In Proceedings of the Proc. 4th Residential Building Design \& Construction Conference. State College, PA, February; 2018; Vol. 28.

70. EU Commission Recommendation (EU) 2019/1660 of 25 September 2019 on the implementation of the new metering and billing provisions of the Energy Efficiency Directive 2012/27/EU; 2019; Vol. 275;

71. ACEEE Guidelines for Low-Income Energy Efficiency Programs Available online: https://database.aceee.org/state/guidelines-low-income-programs (accessed on Jun 27, 2020).

72. Kolokotsa, D.; Rovas, D.; Kosmatopoulos, E.; Kalaitzakis, K. A roadmap towards intelligent net zero- and positive-energy buildings. Sol. Energy 2011, 85, 3067-3084, doi:10.1016/j.solener.2010.09.001.

73. Lu, Y.; Wang, S.; Zhao, Y.; Yan, C. Renewable energy system optimization of low/zero energy buildings using single-objective and multi-objective optimization methods. Energy Build. 2015, 89, 61-75, doi:10.1016/j.enbuild.2014.12.032.

74. EPA Greenhouse Gas Equivalencies Calculator Available online: https://www.epa.gov/energy/greenhouse-gas-equivalencies-calculator (accessed on Jun 25, 2020). 